Article

\title{
An Inclusive Model for Assessing Age-Friendly Urban Environments in Vulnerable Areas
}

\author{
Raquel Agost-Felip ${ }^{1,2}$ (D), María José Ruá ${ }^{2,3, *(\mathbb{D})}$ and Fatiha Kouidmi ${ }^{1}$ (D) \\ 1 Departament of Developmental, Educational and Social Psychology and Methodology, Universitat Jaume I, \\ 12071 Castelló de la Plana, Spain; ragost@uji.es (R.A.-F.); al243181@uji.es (F.K.) \\ 2 Local Development Interuniversity Institute (IIDL), Universitat Jaume I, 12071 Castelló de la Plana, Spain \\ 3 Departament of Mechanical Engineering and Construction, Universitat Jaume I, \\ 12071 Castelló de la Plana, Spain \\ * Correspondence: rua@uji.es
}

Citation: Agost-Felip, R.; Ruá, M.J.; Kouidmi, F. An Inclusive Model for Assessing Age-Friendly Urban Environments in Vulnerable Areas. Sustainability 2021, 13, 8352. https:// doi.org/10.3390/su13158352

Academic Editor: Pilar Mercader-Moyan

Received: 2 July 2021

Accepted: 20 July 2021

Published: 27 July 2021

Publisher's Note: MDPI stays neutral with regard to jurisdictional claims in published maps and institutional affiliations.

Copyright: (C) 2021 by the authors. Licensee MDPI, Basel, Switzerland. This article is an open access article distributed under the terms and conditions of the Creative Commons Attribution (CC BY) license (https:/ / creativecommons.org/licenses/by/ $4.0 /)$.

\begin{abstract}
Population aging is becoming a major challenge in many countries. This paper deals with the elderly's specific needs in the public open space as it can play a significant role in their social inclusion and could be especially relevant in deprived areas. The main goal is to build a model to evaluate the vulnerability of the public space by focusing on the elderly's needs, using indicators. A previous analysis of the scientific and policy-oriented literature and of the technical standards and regulations linked with accessibility and social aspects that affect the elderly in urban areas was performed to identify the main dimensions for evaluation. The interjudge agreement technique was applied to validate the indicators with a panel of experts in technical and social disciplines. The model was applied to a vulnerable area in Castellón (East Spain), based on indicators adapted to the specific context features. The agreement level reached by experts was used to weight the indicators. The application of the model permitted the vulnerability in the suggested dimensions to be estimated and a global integrated index of vulnerability in the area to be calculated. It could assist in urban planning decision making toward age-friendly and, therefore, inclusive cities.
\end{abstract}

Keywords: neighborhood regeneration; urban realm; accessibility; social inclusion; active aging; social services

\section{Introduction}

According to the International Longevity Forum, in 2018 there were more people older than 65 years than children under the age of 5 for the first time in history. Besides, and predictably, between 1950 and 2050, people aged over 80 will increase from 14 to 379 million. Consequently, the elderly's needs are becoming progressively more relevant. Many countries face major challenges to ensure that their health and social systems are ready to make the most of this demographic shift. The World Health Organization (WHO) has been warning about aging since the 1980s. In 1982, Vienna held the first World Assembly on Aging, where countries adopted the International Plan of Action with a variety of health and nutrition, employment and income security, education, social welfare housing, and environment initiatives. It was continued in 2002 at the Madrid Second World Assembly on Aging, where the key challenge was "building a society for all ages".

According to European Union (EU) data, in 2060, about 30\% of people will be aged older than 65 , and $12 \%$ will be 80 years or older. Regarding the urban context, governments, authorities, politicians, and economists must change their approach in relation to cities' development and management, especially public spaces [1].

In line with sustainable development goals (SDG) (UNO, 2015) and the New Urban Agenda (2016), architecture and urbanism should ensure people-centered and inclusive built environments. It is an acceptable notion that senior citizens very often encounter serious problems caused by insufficient mobility and less socialization than other inhabitants. 
Therefore, accessibility to urban spaces is crucial for welfare in urban communities [2], and the elderly can be considered a vulnerable population.

This paper deals with the elderly's specific needs in the public open spaces of built environments given increasing population aging and the exclusion and isolation from society that this population may suffer due to deficiencies of built environments, which may be particularly serious in deprived areas. The main goal is to build a model to evaluate the vulnerability of public spaces by focusing on old people and using key influential aspects in urban spaces to promote their inclusion in city life, particularly in deprived neighborhoods where residential and social vulnerabilities usually concur.

To this end, our analysis is twofold: on the one hand, the technical perspective is examined, especially those factors linked mainly with accessibility and livability in the public space; on the other hand, the social perspective that considers the actual demographic situation and the specific needs and available services for the elderly in the urban context. The practical implementation of measures to improve the elderly's welfare needs to acquire profound knowledge of their specific needs and the suitability of today's existing instruments to ensure their quality of life. For vulnerable populations, the Social Welfare Services provided by Administrations are vital because they have first-hand information $[3,4]$. As a novelty, this work analyses and incorporates social indicators from Social Welfare Services' potential information by considering that vulnerable areas should be prioritized to undertake urban interventions that increase social inclusion. The first point of view is linked with the physical context, which is the urban fabric, and the second one is connected to the co-existing social fabric. The combination of both perspectives is a must in a people-centered urban model.

A previous theoretical framework was constructed based on the scientific and policyoriented literature and also on the technical standards and regulations connected to accessibility and the social aspects that affect the elderly in urban areas. From this review, the main dimensions to build up a standardizable evaluation model were proposed. Then, the evaluation model was applied to a previously identified vulnerable area in the city of Castellón (East Spain). The model was based on indicators, which were selected after considering the technical and social perspectives and were adapted to the specific context's features. To validate the indicators, a panel of experts in technical and social disciplines selected the appropriate indicators in the study area to confer them proper weights in the vulnerability evaluation The local application was twofold: on the one hand, the accurate diagnosis and practical implementation required a microscale analysis in order to detect the actual needs of the elderly people in the area and to design ad-hoc solutions. On the other hand, the model was intended for deprived areas, and the city's recent Urban Land Plan identified the vulnerable neighborhoods. It would be possible to extrapolate the dimensions of analysis proposed after the desk review, in Section 3, to other cities, although an analysis of the local features should be undertaken thereafter in order to select appropriate indicators for the suburban area. The selection of the specific neighborhood in the city was made considering the highest aging ratio, but it would also be applicable to other areas in the city.

\section{Materials and Methods}

Work Stages and Structure

Figure 1 presents the stages followed in this work, together with the qualitative and quantitative methodologies and the main results obtained from each stage. 


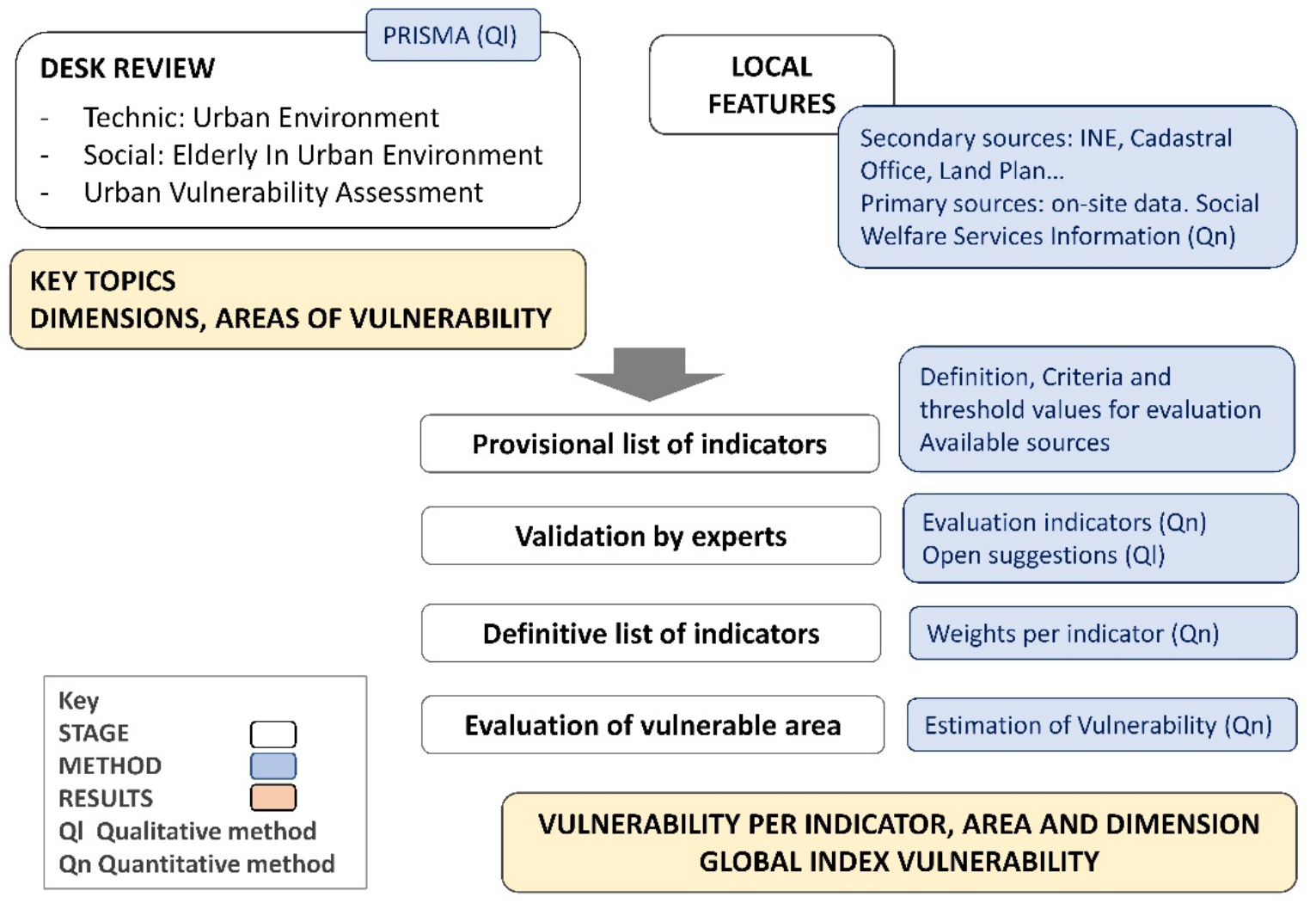

Figure 1. Stages, methodology, and results.

A theoretical framework was built from the analysis of the literature by identifying the key factors and requirements to obtain a model to evaluate inclusiveness in open spaces in urban environments by focusing on senior citizens' needs. The main key topics, identified from the literature review, are presented in Section 3. Sections 3.1 and 3.2 after considering the technical view and the social view. Key factors, such as accessibility in built environments and technical requirements, were examined together with the analyses of the elderly's needs, including the WHO's age-friendly city (AFC) concept and social sustainability from SDG. In addition, Section 3.2.3 introduces the relevance of the implementation of policies to materialize the inclusion of the elderly and how local administrations should use the resources to this end. Finally, previous studies have focused on vulnerability evaluations also being examined to prioritize interventions in deprived areas, presented in Section 3.2.4. From this multidisciplinary review, implementing the Preferred Reporting Items for Systematic Reviews and Meta-Analysis methodology (PRISMA), a standardizable model of dimensions and areas was suggested to evaluate vulnerability. Next, the selected area and its particular characteristics are presented in Section 4.1 to find the appropriate indicators that adapted to both site characteristics and available information. Section 4.2 includes the indicators for the evaluation; first, a provisional ad hoc list of indicators is presented, and the indicators were validated by the interjudge agreement technique. Some experts in the multifaceted topic, with profound knowledge about the selected area, analyzed and evaluated the provisional indicators. From their feedback, a final list of indicators was drawn up and applied to the selected area. Section 5 introduces the main work issues for discussion, which leaves room for further research in this field and summarizes the main reached conclusions.

The following section presents the literature review on the main technical and social factors. From this starting point, the initial list of indicators for the evaluation model was built up and reviewed by some experts to decide on the definitive list. The model was applied to a selected vulnerable area by drawing some conclusions to suggest interventions 
in urban open spaces that could improve the quality of life of citizens in general and of the elderly in particular.

\section{Literature Review}

Figure 2 illustrates the identification of the influential variables obtained from a literature review and the theoretical framework connected to the technical and social perspectives using the PRISMA methodology and by searching for references from different databases. The source was the Scopus database. The selection of the updated references (2005-2021), with the proper keywords and the subject area limited the number of references to a group, and two reviewers checked both titles and abstracts. They selected some final studies that were directly linked to the scope of this work, which were reviewed in depth. From the technical perspective, keywords "Urban OR Building" AND "Accessibility OR Design" AND "Elderly OR OLD-AGED" and the subject area "Engineering" yielded 24 references. Likewise, from the social perspective, keywords "Active Ageing" AND "Urban OR Planning" and the subject area "Engineering" produced 32 references.

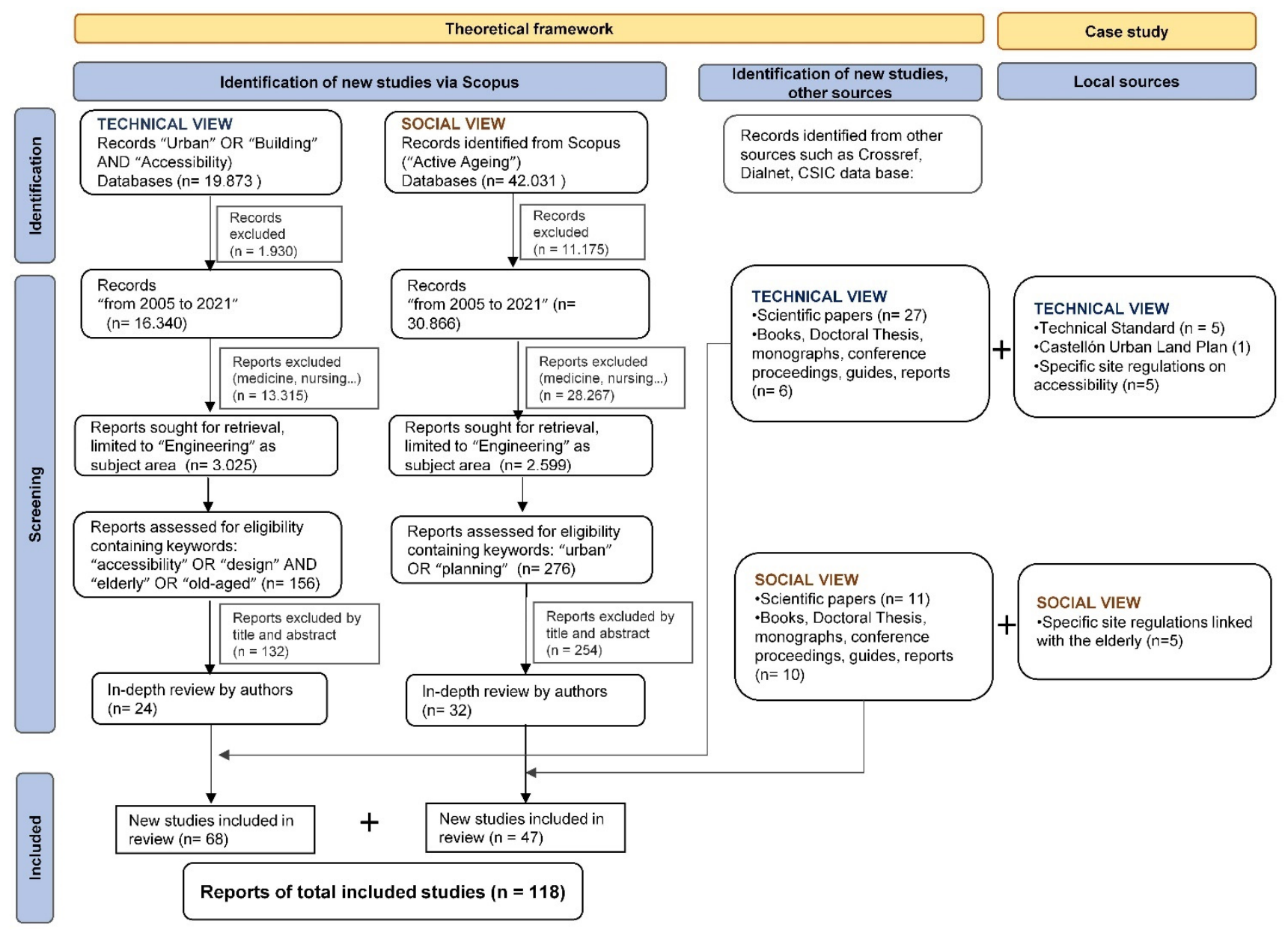

Figure 2. Illustration of the PRISMA methodology (adapted from [5]).

Other sources such as Dialnet, Cross Ref or the CSIC database were used, and not only scientific references, but also other sources applicable to this study were found, such as reports, guidelines, handbooks, etc.

In the physical urban context, a review of the Technical Standards connected to accessibility in built environments was also done. The regulations currently in force and linked with urban issues and accessibility in the study area were examined to identify the key factors to be included in the model. 
Some WHO recommendations for the Active Aging (AA) population and AFC were reviewed to obtain some key ideas. Similarly, the targets included in the United Nations' SDG related to the elderly were analyzed. Some specific-context policies were examined by focusing on the case study to apply the model. Finally, the role of the Social Welfare Services available for the elderly and for the vulnerable populations in the area was also observed to identify the instruments available to support them in urban areas. The information and aid from this part of Local Administrations were crucial to gain a complete picture of the elderly's situation at the local scale.

\subsection{Technical Conditions of Public Spaces}

The analysis of the literature showed that accessibility is vital to ensure the inclusion of citizens with mobility issues. Accessibility has evolved in the public space from an inexistent consideration to become a universal design concept in every product, including urban spaces. The main conclusions of the review varied and are summarized as follows:

The relationships between the city's sociality and spatiality are highlighted by many authors [6-8]. The universal design concept inevitably arises [9-15], and urban universal accessibility is specifically analyzed by some authors [16,17].

The latter is connected to everyone's right to mobility regardless of disability, age or gender. Therefore, some authors connect this to social sustainability and social justice concepts [18-24]. In line with this, some authors point out some factors, such as density, accessibility, mobility, integration (connections and street networks), diversity of services, mixed use, environmental quality, safety, and social capital (sense of belonging, participation) [25], while others highlight that accessibility and quality of social life, conservation of resources, quality of built environments, protecting disadvantaged groups, and commercial and economic opportunities are observed in urban renewal practices [26]. Some factors underlying social factors have been suggested, such as health and physical comfort, accessibility, integration, economy, and participation [27]. Ahrentzen and Tural reviewed 37 research articles and identified six built environment characteristics: barriers, supports and features that fit; spatial organization and layout; environmental cues; ambient qualities; assistive technologies; and gardens and outdoor spaces. They concluded that accessibility-oriented features dominated the studies [28].

La Rosa et al. considered demands and preferences for different social groups' accessibility, e.g., children and the elderly [29], and some studies focus on the elderly's specific accessibility needs [30-34].

Other authors centered on specific infrastructures; for example, Basbas et al. (2010) analyzed the facilitation of pedestrian trips in urban areas by pointing out that the elderly usually face more difficulties during trips on foot than other age groups [35]. Wen et al. (2018) identified some landscape features desired by old-aged people, such as natural, esthetic, comprehensible, and diverse, with accessible and well-maintained infrastructure and facilities [36]. Shan et al. (2020) examined the acoustic environment in the elderly's public activity space to design a new elderly healthy urban park environment [37], which they associated with a healthy and active way of living [38,39]. Tao and Cheng (2019) analyzed the elderly's spatial accessibility to healthcare services in Beijing [40]. Brake (2008) identified appropriate options for delivering urban transportation to older people [41].

In order to examine the technical perspective, some technical standards containing requirements for an accessible urban and built environment were reviewed. UNE is Spain's only Standardization Organization, designated by the Spanish Government. Although standards are voluntarily applied, they are an excellent guide to detect the key topics that achieve complete accessibility in urban spaces and are basic guides to legislate in specific technical topics. Six documents were reviewed: two standards on Universal Accessibility (UNE 170001-1, Universal accessibility. Part 1: MGLC criteria to facilitate accessibility to the environment and Universal accessibility and UNE 170001-2 Part 2: Accessibility management system), and four more standards that focus on built environments (UNE 41510 Accessibility in urbanism. UNE 41524 Accessibility in building. General design rules 
for spaces and elements in buildings. Links, equipment and use. UNE-ISO 21542 Building construction. Accessibility and usability of built environments).

Some policy-oriented references were also examined, such as reports, guides or mandatory regulations for the practical implementation of accessible spaces. As the case study is located in Spain, complete national, regional, and local regulations are linked to accessibility in built environments [42], which were identified and analyzed. In Spain, the main reference is the Technical Code for Buildings (CTE, Código Técnico de la Edificación, in Spanish), specifically Basic Document SUA9 on Accessibility to buildings and nearby urban spaces (SUA, standing for Seguridad de Utilización y Accesibilidad, in Spanish, meaning Secure Use and Accessibility). Regionally in Spain, as competences on urban matters are delegated to the Autonomous Communities, the main reference in the Valencian Region, where Castellón is located, is Decree 65/19, which regulates accessibility in buildings and public spaces (Decreto 65/2019, de 26 de abril, del Consell, de regulación de la accesibilidad en la edificación y en los espacios públicos). Locally, Local Administrations are in charge of managing urban spaces. The Municipal Ordinance on Accessibility in Castellón was adapted to the city's specificities (Ordenanza Municipal de Accesibilidad, 26 April 2007).

\subsection{Senior Citizens' Needs in Public Spaces}

The social view completed the analyses and considered some people-centered factors. When talking about the elderly in society, the AA and AFC concepts arise. They have been promoted by the WHO since the early 1990s and have been largely analyzed in the literature. Moreover, the available tools that Local Administrations have to support the elderly and to take care of their needs were analyzed. In this work, Social Welfare Services were considered to play a crucial role with vulnerable populations [43]. They face the difficulties that the most vulnerable populations encounter in the city and provide exact information to adapt the social specificities of the case study. This section summarizes all these factors.

\subsubsection{Active Aging}

Active aging (AA) is defined as "the process of optimizing opportunities for optimizing opportunities for health, participation and security in order to enhance quality of life as people age" (WHO, 2002). Six key factors are considered to influence the promotion of AA: health and social services; healthy way of life; biology and genetics; physic environment; social environment; economic situation.

The importance of living healthy aging is highlighted by many authors. AA is the logical consequence of the demographic, social, economic, and political changes that have been taking place in societies worldwide [44]. Some authors indicate that the objective of AA is to maintain the elderly's physical activity and their productivity, as well as life expectancy [45]. Others define healthy aging as the process of developing and maintaining the (mental and physical) functional capacity for well-being in older age [46], while some confirm that AA is built on four main pillars: health, participation of the elderly, safety to improve the lives of the elderly as they get older, and lifelong learning [47,48].

Afacan (2013) conducted a study in the city of Ankara and indicated that an inclusive open environment not only allowed elderly people to feel safer, but promoted more regular uses of urban spaces. It highlighted accessibility and plain simple signage as key factors to increase the aging population's social participation [49]. Elsawahli et al. (2017) concluded that in the public realm, older adults are sensitive to poor lighting and inadequate walkway conditions, and regular maintenance is required to promote their physical activity [50]. Focusing on mobility, Musselwhite et al. (2015) pointed out that connection to communities and social networks enables older people to contribute to and connect with society, and mobility is associated with positive mental and physical health by facilitating physical activity and independence, while reducing social isolation [51]. Regarding housing needs, Gharaveis (2020) indicated that design interventions can increase physical functioning both inside and outside long-term residential facilities [52]. Some authors point out that aging 
should be seen as a life opportunity, a challenge and an enjoyment for elderly people who wish to become active members of society [53-55].

The AA Index (AAI), created in 2012 by the United Nations Economic Commission for Europe (UNECE), together with the European Commission Directorate General for Employment, Social Affairs and Inclusion and the European Centre for Social Welfare Policy and Research, measures the extent to which older people live independent lives, participate in paid employment and social activities, and their capacity to actively age. The index is calculated from 22 indicators grouped into four domains: Employment; Participation in Society; Independent, healthy and secure living; Capacity of enabling environment for AA. From the results, differences appear among countries, with Sweden at the top, followed closely by Denmark. The UK, Italy, Portugal, Spain, and Malta are middle-ranked countries, with Greece and many Central European countries at the bottom, which highlights having to make more policy efforts in the latter countries [56]. Thalassinos et al. (2019) conducted research to assess how the AAI correlated with economic and labor market credentials and how it would impact EU Member States' economic development to find important dissimilarities among them [57].

\subsubsection{Age-Friendly City}

The Vancouver Protocol (2006) pointed out the relationship between aging demographics and urban processes. In the urban environment, the AFC is gaining more relevance because the elderly population represents a high and growing percentage of the population in society, hence the need to respond adequately to their daily and basic needs. Eight domains should be observed in an AFC: Outdoor Spaces and Buildings; Transportation; Housing; Respect and Inclusion; Social Participation; Civic Participation and Employment; Communication and Information; and Community Support and Health Services [58,59].

De Oliveira et al. (2019) found a huge number of references in the scientific literature from 2007 to 2017 about the implantation and evaluation of AFCs in the world and highlighted international concern about age pyramid change and longevity [60]. RémillardBoilard et al. (2021) compared the experience of eleven cities located in different countries. Their study explored the key goals, achievements, and challenges faced by local agefriendly programs and identified four priorities: changing the perception of older age, involving key actors in age-friendly efforts, responding to the diverse needs of older people, and improving the planning and delivery of age-friendly programs [61]. Sengers and Peina (2021) focused on age-friendly housing options by considering private spaces in the city [62], while Marquet el al. (2017) explored the effects of neighborhood morphology and walkability in active travel patterns of aging older adults [63].

Regarding social aspects, some authors point out that the elderly living in unsafe places with architectonic barriers are more likely to suffer isolation and depression, and the social network should be maintained to keep quality of life high. Some point out that age is not very often explicitly integrated into urban socio-spatial inequality analyses [64], while others highlight that older adults, especially those living alone with no family support, are particularly sensitive to the local environment [65]. Iamtrakul et al. (2019) conducted research to understand the health-related problems of age groups between different life styles and neighborhood characteristics in Thailand and recommended encouraging AA by optimizing health, participation, and security opportunities to enhance quality of life [66]. Fung (2020) indicated that the community support of AA becomes a crucial part of the urban neighborhood's collective resilience [67]. Some authors introduced the gender perspective and found that old age punishes women more than men because they live longer and under worse conditions [68,69]. Flores et al. (2019) evaluated an AFC by analyzing its relationship to life satisfaction by considering the elderly's age cohort variables and whether they live alone or with someone else. Despite differences being found in the various old-aged people groups, they were all domains of outdoor spaces and buildings, and community support and health services were significantly related to life satisfaction [70]. Yung (2016) worked with eight focus groups in elderly community 
centers in two urban renewal districts of Hong Kong and perceived the most important needs, as well as social and physical activities, community life facilities and services, the social network, and a clean pleasant environment [34].

In line with the WHO, the UN SDG aim to develop friendly environments for the elderly by reaching AFC and communities and to reinforce long-duration care [71,72]. When looking at the varied perspectives of SDG, practically all of them present specific targets connected to people's well-being in general, and, in some cases, by focusing on vulnerable populations, including the elderly; for example, targets 2 and 7 of SDG 11 for sustainable cities and communities are set out as "Provide access to safe, affordable, accessible and sustainable transport systems for all, improving road safety, notably by expanding public transport, with special attention to the needs of those in vulnerable situations, women, children, persons with disabilities and older persons" and "Provide universal access to safe, inclusive and accessible, green and public spaces, in particular for women and children, older persons and persons with disabilities", respectively.

Deprived areas and vulnerable neighborhoods face more difficult challenges because of their greater deficiencies, which are implicit given their vulnerability condition [73]. Bayar and Türkoğlu (2021) compared the experiences of older adults living in two neighborhoods of Istanbul (Turkey). They concluded that the city's engagement and sociability level are connected to higher incomes [74]. The study by Carroll et al. (2020) in a deprived neighborhood in Copenhagen found that targeting the appropriate kind of age-friendly programs might enhance empowerment through physical spaces as a starting point for social interaction [75]. Curl and Mason (2019) investigated how the environment influences the walking and well-being of the older adults living in disadvantaged urban areas [76].

Some relevant studies have centered specifically on the elderly in built environments and are summarized in Table 1.

Table 1. Relevant studies about elderly people's interaction with urban environments.

\begin{tabular}{|c|c|c|}
\hline Research Paper & Topic & Main Findings \\
\hline [77] & $\begin{array}{l}\text { Environment influences older adults' } \\
\text { health and activity participation }\end{array}$ & $\begin{array}{l}\text { Some limitations in the literature. Key topics to consider in future } \\
\text { research: climate, pollution levels, street lighting, traffic } \\
\text { conditions, accessibility and appropriateness of services and } \\
\text { facilities, socio-economic conditions, esthetics, pedestrian } \\
\text { infrastructure, community life, exposure to antisocial behavior, } \\
\text { social network participation, environmental degradation, } \\
\text { urbanism level, exposure to natural settings, familiarity with the } \\
\text { local environment, among others. }\end{array}$ \\
\hline
\end{tabular}

Housing, social participation, respect, civic participation and

[78] Determinants of an age-friendly community in Melaka (Malaysia)

Perceived suitability of urban and

[79] housing environments for aging populations in Spain and Mexico

[80]

Older adults' experiences with outdoor space and buildings

[81]
Quantifiable spatial indicators to assess local lived environments according to AFC domains (Australia) employment, health services provided for the elderly, and outdoor spaces and environment for the elderly to perform physical activities; only respect, social participation, and outdoor spaces were significant.

35 variables for each scale, neighborhood-public space and buildings-dwellings in Spain and Mexico. In both cases, indicators are organized as seven dimensions: design, accessibility \& mobility, comfort, maintenance, security and health, use and control, and stimulus.

They found crucial accessibility and appropriate infrastructure.

Remarkable indicators: outdoor spaces and buildings: walkability for transport; access to public open space within $400 \mathrm{~m}$; intersections serviced with pedestrian crossings; access to public seating; access to public toilets; accessible buildings. social participation domain: access to neighborhood

houses/community centers; recreational services that cater for older people. The respect and social inclusion domain: access to social clubs/senior citizens clubs. The civic participation and employment dimension: proportion of the population aged $60+$ years regularly volunteering; proportion of the population working beyond the official retirement age. 
Table 1. Cont.

\begin{tabular}{cll}
\hline Research Paper & Topic & Main Findings \\
\hline & & $\begin{array}{l}\text { Five domains: personal characteristics, place-related, } \\
\text { socio-economic environment, governance, and health-related; } 15 \\
\text { criteria and } 99 \text { indicators. Some noteworthy indicators: the } \\
\text { place-related dimension and public open space criteria: street }\end{array}$ \\
& $\begin{array}{l}\text { lighting, the area to open spaces ratio, public recreation and open } \\
\text { spaces, quietness, maintenance. The socio-economic dimension: } \\
\text { quality of life, social interaction, happiness, social inclusion, social }\end{array}$ \\
& Measurement scale & inequalities, social participation, social support. The health \\
& dimension: social life or sense of community.
\end{tabular}

Index of quality of life for the elderly;

[83] local territorial context; neighborhood level
The index was calculated from objective and subjective indicators. It considers five broad areas, namely, quality of life, business and labor, services and environments, population, and leisure, included in two main streams: elderly quality of life and key urban environment features.

The problems which the elderly frequently encounter in public open spaces: pavements and roads, pollution, safety, insufficient maintenance and management, traffic and socio-cultural problems.

It highlights the effect of green public spaces on the average urban quality of life and stresses that levels of safety, maintenance, accessibility, and availability of equipment are key factors of well-being.

Mobility, accessibility, and availability of open spaces connected to the elderly's satisfaction with the out-of-home environment, encouraging the availability of public open spaces and pedestrian-friendly neighborhood environments.

[86] Focuses on public open spaces

Certain conclusions can be drawn from the review of the studies in Table 1. Firstly, while some of the studies rely on some or all of the AFC domains $[78,80,81,86](6,8,2$ and 2 domains, respectively), others propose a new domain structure containing different variables or indicators $[79,82,83]$. Some authors draw conclusions from a desk review on the topic, for example, in [77], 83 studies were examined, concluding that not only should environmental aspects be included when analyzing influences on older adult health, but also personal circumstances. The latter is also present in other studies, where the subjective factors are considered, for example, in [79], where variables such as "self-perceived quality of life" or "place attachment", or in [83], where 13 out of the 29 indicators are "Subjective Indicators". On the other hand, the desk review of other studies is focused on physical attributes, for example, mobility, accessibility, and availability of open spaces [84] or green spaces [85]. Reference [80] provides a different approach connecting AFC to environmental justice. The authors consider that the work is a useful framework for social workers to systematically document and evaluate their age-friendly community efforts. This is aligned with our work, which proposes the involvement of Social Services in the diagnosis, considering its application to vulnerable areas. The scale of application also differs depending on the study. In some target villages or cities $[78,79,81,86]$, others are applied at a suburban scale [83-85]. As for the implications of the studies, some could be implemented in local, national, and, sometimes, international policy making and planning [78-83], while others have a more regional or local focus [84-86].

\subsubsection{Policies That Address the Elderly's Social Inclusion}

Population aging is a challenge for governments to comply with international commitments to human rights and for the State because it must act to guarantee these social rights by protecting and safeguarding them with public policies [87]. Aging European countries have widespread implications for current and future social and economic policies 
all across Europe [88]. Kurek et al. (2011) point out that the EU response to the aging population challenge by the 'AA' policy aims to increase the employment rate of elderly workers and to raise their retirement age and also refers to their participation in social, economic, cultural, spiritual, and civic affairs [89].

In the EU, each Member State undertakes its national strategy by attending to its particularities. Eurostat data show that the prospected demographic trend in Spain increases for the general population until 2050, but decreases after this period. When we look at the projected old-rate dependency ratio, Spain is one of the Member States with the highest ratio in 2100, which doubles from 29.3 to 60.1. Currently, Spain has a National Strategy for Older People's AA and for their Good Treatment for 2018-2021. It contains five main strategic lines: 1 . improve the rights of older workers and extend working life; 2. participation and decision making in society; 3 . promote healthy independent living in suitable and safe environments; 4 . non discrimination, equal opportunities, and pay attention to situations of fragility and more vulnerability; 5 . avoid mistreating and abusing the elderly. Each line of action has specific targets.

Under the national strategy umbrella, all Spanish Autonomous Communities develop their regional strategy. In the Valencian Region, the intention of the Valencian Plan for Inclusion and Social Cohesion (VICS, 2017) is for social inclusion to reach all citizens. The work of Garrido and Jaraíz (2017) studies the influence of territorial-urban policies on social inclusion [90]. According to Caballer et al., (2017), who analyzed the Regional Valencian Government policy, by focusing on old-aged people, it aims to improve their lives by better health services, accessibility to buildings and dwellings, public transport, promoting education, etc. [91].

The implementation of this plan relies, among other factors, on the important role of Social Welfare Services to support vulnerable populations. Law 3/2019, on Inclusive Social Services of the Valencian Community, is the reference regulation. Its professional performance includes protecting the elderly in vulnerable situations and also supporting care givers (Article 36). It also highlights the importance of vulnerable spaces that, due to their urban/residential, social, labor or economic characteristics, require integrated action (Article 25). Article 25.3 points out the deficit of community or socio-cultural equipment or resources, the existence of substandard housing or difficulties for urban mobility, as some aspects that indicate vulnerable spaces.

It is important to consider that municipalities are the last step on the scale to ensure old-aged people's care. The Social Welfare Service Departments in municipalities are responsible for guaranteeing that this population stratum is included. The city of Castellón joined the Network of Cities and Communities Friendly to the Elderly at the end of 2014. The diagnostic stage was completed in two years. Through a plenary agreement dated November 30, 2017, the Action Plan of the project "Castelló, a friendly city for the elderly" for the 2017-2019 period was approved and included the AFC domains to be improved.

\subsubsection{Vulnerability Evaluation}

The scope of this work ultimately centered on evaluating vulnerability by considering technical and social perspectives. On the one hand, the analysis focused on a vulnerable urban area with many deficiencies in the urban and built spheres; on the other hand, senior citizens' needs are placed in the spotlight by assuming old age to be a life cycle stage that can be potentially reached by every inhabitant.

Table 2 presents some remarkable works on this topic in the Spanish context. They all fall within the sustainability framework, including economic and social features and characteristics connected to the built environment. Some look at social issues in more depth, while others are more urban-centered. 
Table 2. Summary of studies on vulnerability in urban environments.

\begin{tabular}{|c|c|c|}
\hline Reference Study & Scale & Dimensions and Examples of Indicators \\
\hline [92] & Regional & $\begin{array}{l}\text { Nine areas: demography; health; education; employment; housing; urbanism; social } \\
\text { relations; participation; perceived and projected vulnerability. }\end{array}$ \\
\hline [93] & National & $\begin{array}{l}\text { Economic subsystem: } \\
\text { Demographic: population evolution, dependence index, etc. } \\
\text { Economic: income, unemployment, etc. } \\
\text { Social subsystem: } \\
\text { Resources: institutional, communitarian, etc. } \\
\text { Social cover: beneficiaries of subsidies; support in the area, etc. } \\
\text { Urban subsystem: } \\
\text { Location: isolation; proximity to infrastructures, etc. } \\
\text { Infrastructures: education; health; urban facilities (pavement, lighting, etc.) }\end{array}$ \\
\hline [94] & National & $\begin{array}{l}\text { Social level: Percentage of unqualified population; percentage of illiterate peoples; female } \\
\text { unemployment, etc. } \\
\text { Demographic and family situations: percentage of the population > } 65 \text { years; dependence } \\
\text { index; household composition, etc. } \\
\text { Living conditions: average dwelling area per inhabitant; maintenance of buildings, etc. }\end{array}$ \\
\hline [95] & National & $\begin{array}{l}\text { Socio-demographic vulnerability: percentage of population }>64 \text { years; over-aging index; } \\
\text { immigrants index; percentage of single-parent family, etc. } \\
\text { Socio-economic vulnerability: unemployment; illiterate population, etc. } \\
\text { Residential vulnerability: percentage of dwellings }<31 \mathrm{~m}^{2} \text {; percentage of badly conserved } \\
\text { dwellings, etc. } \\
\text { Subjective vulnerability: percentage of dwellings affected by nearby green areas; percentage } \\
\text { of dwellings affected by inefficient communications, etc. }\end{array}$ \\
\hline [96] & Regional & $\begin{array}{l}\text { Residential vulnerability: poor living conditions; evictions, etc. } \\
\text { Economic vulnerability: unemployment, reduction in family income, etc. } \\
\text { Social vulnerability: welfare cuts, health cuts, etc. }\end{array}$ \\
\hline$[97,98]$ & National & $\begin{array}{l}\text { Urban vulnerability: green areas; accessibility to health services, etc. } \\
\text { Building vulnerability: constructive quality, accessibility in residential buildings, etc. } \\
\text { Economic vulnerability: location of proximity services; socioeconomic stratification, etc. } \\
\text { Socio-demographic vulnerability: population older than } 65 \text { years; level of education, etc. }\end{array}$ \\
\hline [99] & Regional & $\begin{array}{l}\text { Residential vulnerability: accessibility in residential buildings, average area/inhabitant, etc. } \\
\text { Socio-demographic vulnerability: dependence index with gender perspective; immigrants, } \\
\text { etc. } \\
\text { Socio-economic vulnerability: illiterate population; income; unemployment, etc. }\end{array}$ \\
\hline$[100,101]$ & Local & $\begin{array}{l}\text { Urban vulnerability: urban density; proximity to public transport, etc. } \\
\text { Building vulnerability: energy efficiency; accessibility, etc. } \\
\text { Socio-demographic vulnerability: population older than } 65 \text { years; immigrants, etc. } \\
\text { Socio-economic vulnerability: social subsidies; level of education, etc. }\end{array}$ \\
\hline
\end{tabular}

In this work, we pay attention to the role of Social Welfare Services in intervening in deprived urban areas. They possess plenty of valuable information because they manage the resources that the Local Administrations provide to the most vulnerable population. On a regional scale, Giménez-Bertomeu et al. (2020) prepared a research report for the Regional Valencian Government [92]. It intended to incorporate vulnerability indicators from Social Services' information, which is aligned with the scope of this work. They included nine areas: demography; health; education; employment; housing; urbanism; social relations; participation; perceived and projected vulnerability. They concluded that socio-demographic and socio-economic dimensions present only a few dimensions, while physical variables are better defined. They also emphasized the lack of subjective variables and pointed out that information should be disaggregated into specific population groups (the elderly, traders, experts, etc.) when, for example, it comes to difficulties in urban mobility, deficiencies in lighting or sanitary infrastructures, among others. One very important conclusion was reached: the complete lack of sources of information on 
an intraterritorial scale and in relation to environmental aspects of material (equipment, infrastructures) and immaterial (perceptions, opinions, feelings about the territory) natures.

\section{Results}

From the analysis of the above references, the key topics to evaluate the accessibility of public open spaces were proposed by separately considering the technical and social perspectives. They were grouped and formed three dimensions that presented different areas to organize the several features connected to the use of public spaces:

1. Dimension Urban and Building Vulnerability (UBV)

- $\quad$ Area Urban environment (UE): to measure aspects linked with the urban realm

- $\quad$ Area Infrastructures (I): to detect lack of important infrastructures connected to accessibility and safety in public spaces

- Area Facilities (F): to evaluate the presence or absence of basic services for the elderly (e.g., health)

- $\quad$ Area Buildings (B): to evaluate access to buildings

2. Socio-Demographic Vulnerability (SDV): this dimension was divided in two areas

- Demographic (D), to include the demographic features of the study area

- $\quad$ Social (SO), to evaluate social aspects in the area, such as support from local administrations or the elderly's participation in the area

3. Socio-Economic Vulnerability (SEV): it reflects the economic features in the area

\subsection{Case Study}

Castellón is located in the Valencian Region (East Spain). It is a medium-sized city with 174,264 inhabitants, (Spanish National Statistics Office, INE, 2020).

The city is divided into nine districts that are, in turn, divided into 110 census sections. There are six administrative structure areas: North, South, East, West, Center, and Grao. The highest percentage of aged-people is identified in the Center administrative district.

On the local scale, García et, al. analyzed and wrote a report to identify vulnerable areas in the city of Castellón according to the city's Land Urban Plan [100]. This was taken as the basis to select the vulnerable area, which was the case study herein analyzed. The particular features, available information, and knowledge about the area allowed us to draw up a tailored list of indicators to be included in the evaluation model.

As seen in Figure 3, the selected case study is a neighborhood located in the Centre district formed by census sections 05005 and 05013. This area was identified as being vulnerable by the recent Urban Land Plan. The coincidence of the neighborhood borders with the census section borders made it easier to find the disaggregated information at the desired level. The neighborhood is characterized by the presence of the Bullring and is limited to the north by the Ribalta Park. The total area covers 58,553.64 $\mathrm{m}^{2}$. According to the Urban Land Plan, some urban features were vulnerable; for example, urban density was 176.93 dwellings / ha, which exceeds the threshold value of 100 dwellings/ha. The nearby park conferred the surroundings green areas, but vegetation is scarce in the neighborhood. Constructions in the building stock are old and obsolete: $77.78 \%$ of the buildings present bad energy performance, $10 \%$ have deficient conservation, and $44 \%$ display poor building quality.

All these features were confirmed during the visit to the neighborhood, when some deficiencies were identified (see Figure 4). Although the Ribalta Park is close to the area, green areas and vegetation are scarce in the neighborhood, and the presence of trees should be increased to create shaded areas and to reduce the heat island effect. Moreover, existing trees have inappropriate tree pits. Some problems linked with accessibility in pedestrian areas also appear: in many spots, pedestrian routes are occupied by commerce or parked cars, most sidewalks are narrow, and the public space generally lacks maintenance. Some buildings are abandoned, and many commercial and residential buildings are not accessible and need wider accesses or ramps to ensure vertical circulation. A high percentage of the 
building stock is old and presents general degradation due to lack of maintenance. The general conclusion reached is that most of the elements considered for urban dimension are better maintained in the main avenues surrounding the neighborhood. However, in the inner parts of the study area, all the urban elements are nonexistent or improperly or badly maintained.

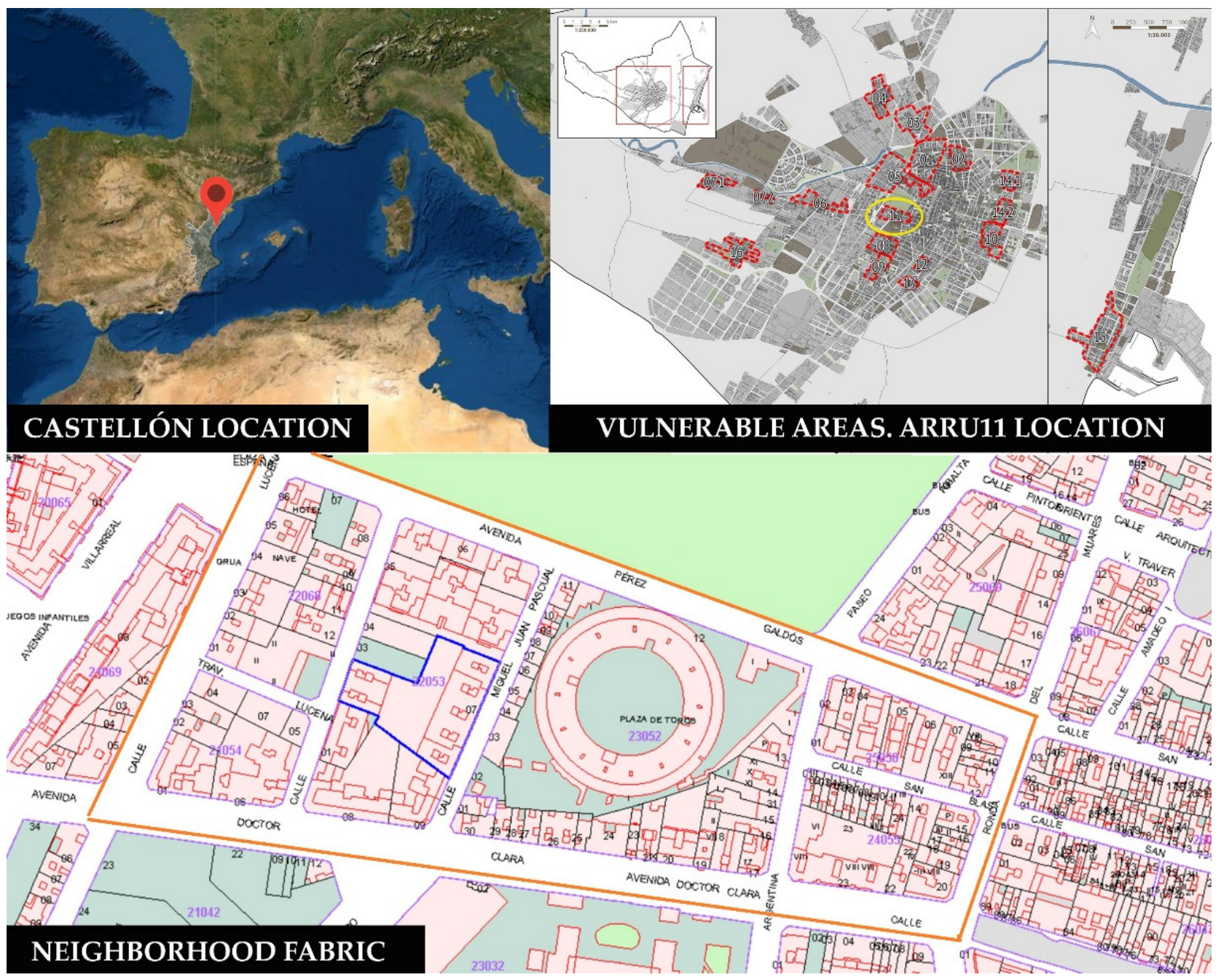

Figure 3. Location of the study area.

Some processes in which citizens participate were also taken into account to devise the Land Urban Plan. The focus groups performed with old-aged people were especially connected to this work because they are considered a vulnerable population group. The main findings of the concerns voiced by the participants were: lack of maintenance and cleaning in public spaces in certain areas, non-accessible transport, need for bike lines, lack of lighting in some spots, etc. [101] (p.102).

According to the 2019 INE data, census section 5005 and census section 5013 had 27\% and $27.9 \%$, respectively, of the population aged older than 65 years, both of which were higher than the city's average value of $18.9 \%$.

As logically assumed, the population in their 80 s faces more mobility difficulties than those in their $60 \mathrm{~s}$. The older populations in the census sections are illustrated in Figure 5 by considering the age ranges of 65-69, 70-74, 75-79, 80-84, and older than 85 years (2019 INE data). Note that senior citizens older than 80 years represent more than $20 \%$ of the population aged older than 65 years in census sections 5005 and 5013. 

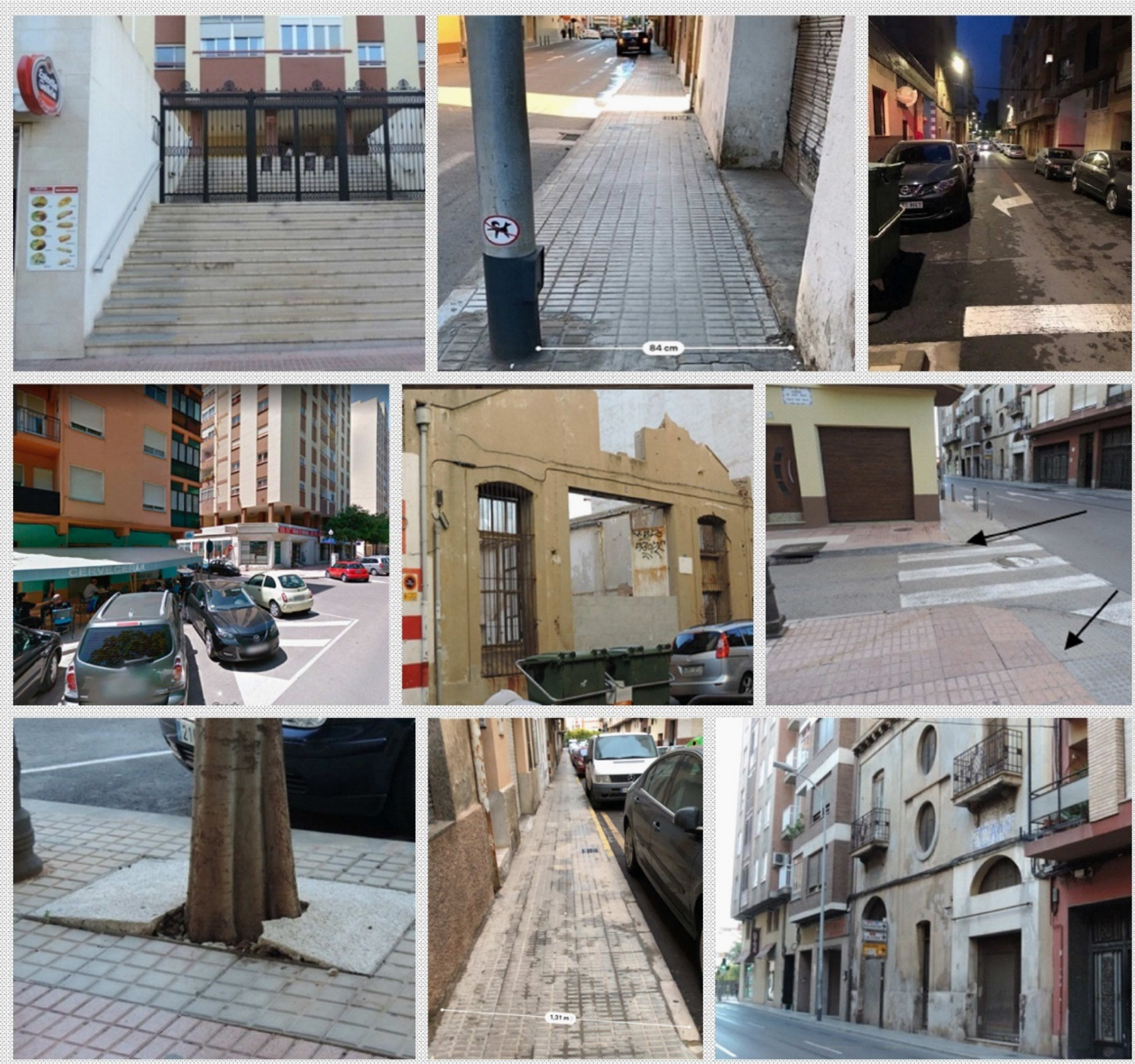

Figure 4. Some problems in the public spaces in the area.

Regarding economic features, the Urban Land Plan report for the identification of vulnerable areas highlighted that Social Welfare Services were required more often than the average and social subsidies, while the dependence aid in this area presented higher values than average. Some economic data, such as income or unemployment in the area, were not directly linked with the elderly, but are good indicators that reflect economic vulnerability. The average income per household in the city is $€ 30,929$, with $€ 26,813$ and $€ 24,964$ in census sections 5005 and 5013, respectively (INE, 2019).

An important indicator to measure social dynamism has to do with civic associations. According to the Municipality, the city of Castellón has 776 registered associations. The general associations per administrative area in the city of Castellón are as follows: 205 are located in the Center District, followed by the East, North, West, South, and Grao Districts, with 158, 148, 117, 80, and 58, respectively. Only 33 are intended for old-aged people, which represent $4.2 \%$. According to Mollar et al., (2020), 18\% of the elderly in Castellón voluntarily participate in associations. There are 20 associations registered in a 
600-m radius from the neighborhood's geometric center. Seven are intended for old people: four are retiree associations, two are day care centers, and one is one of the three C.E.A.Ms. in the city (standing for Centro Especial de Atención a Mayores in Spanish, meaning Elderly Care Center).

\section{Population aged over 64 years per age interval in the study area}

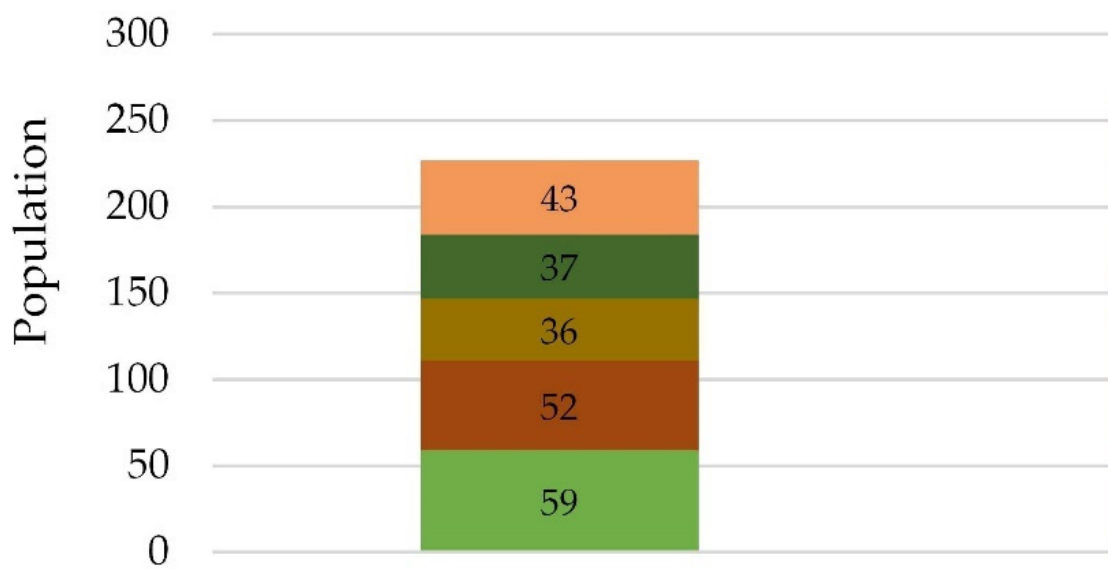

5005

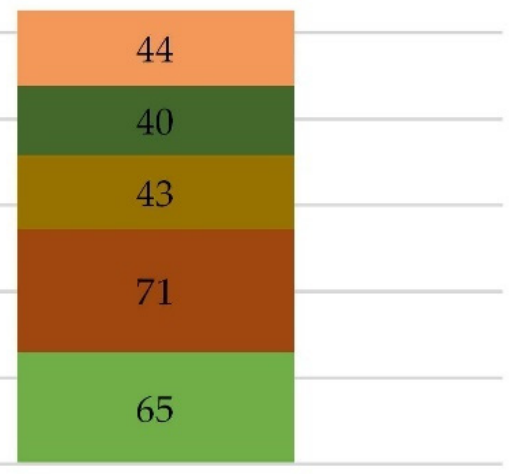

5013

\section{Census section}

\section{$65-69 \square 70-74 \quad \square 75-79 \square 80-84 \square>85$}

Figure 5. Distribution of old people in age intervals in the study area.

The Municipality is active in promoting AA. Specific subsidies are offered for AA ( http:/ / www.castello.es/archivos/387/Anuncio_Concesion_Subvenciones_2020.pdf, last accessed on 31 May 2021). In addition, services for the elderly are provided, such as psychological and legal assessments.

\subsection{List of Indicators for the Case Study}

Having collected data from the case study, a provisional list of 24 indicators, and arranged in relation to dimensions and areas, is presented in Table 3.

In order to validate the indicators, some experts were asked to evaluate them and to make suggestions to improve the model. Interjudge agreement was implemented [102]. This technique is based on the degree of agreement reached by some people of guaranteed experience and professional solvency. The main goal is to reach the maximum consensus.

Selection of experts is based on the following criteria: independence; years of experience, and expertise in accessibility in the urban open space or in social sustainability, and vulnerability. They must all have a similar educational and cultural background [103]. Seven experts were selected: four women and three men, as can be seen in Table 4 . In April 2021, the experts were requested to complete an on-line survey (through Google forms) to evaluate the relevance of the proposed indicators on a scale from 1 to 5 , where 1 denotes not important (NI), 2 means slightly important (SI), 3 suggests not important nor unimportant (NIN), 4 means important (I), and 5 is very important (VI). The survey was completed with two final open questions with which the experts were required to suggest new indicators that were not on the provisional list and to make open suggestions about the model. In June 2021, in a second round, the experts were informed about the results and were asked to evaluate the newly included indicators (by e-mail). By doing so, the level of agreement could be used as an estimation of the weight to be applied to each 
indicator by using weighted average values. Therefore, the definitive model included 27 indicators.

Table 3. Provisional list of indicators.

\begin{tabular}{|c|c|c|}
\hline Dimension & Area & Indicators \\
\hline \multirow{16}{*}{ UBV } & \multirow{7}{*}{ UE } & 1. Green areas \\
\hline & & 2. Daytime acoustic comfort \\
\hline & & 3. Nighttime acoustic comfort \\
\hline & & 4. Accessible paving \\
\hline & & 5. Ramps \\
\hline & & 6. Pavement maintenance \\
\hline & & 7. Pedestrian routes \\
\hline & \multirow{3}{*}{ I } & 8. Accessible public transport \\
\hline & & 9. Lighting \\
\hline & & 10. Adapted traffic lights \\
\hline & \multirow{3}{*}{$\mathrm{F}$} & 11. Health facilities \\
\hline & & 12. Elderly care facilities \\
\hline & & 13. Commercial facilities \\
\hline & \multirow{3}{*}{ B } & 14. Buildings' age \\
\hline & & 15. Accessibility in residential buildings \\
\hline & & 16. Accessibility in non residential buildings \\
\hline \multirow{6}{*}{ SDV } & \multirow{3}{*}{$\mathrm{D}$} & 17. Population older than 64 years \\
\hline & & 18. Immigrants \\
\hline & & 19. Aging ratio \\
\hline & \multirow{3}{*}{$\mathrm{SO}$} & 20. Social services attention to dependency \\
\hline & & 21. Social subsidies \\
\hline & & 22. Participation in the community \\
\hline \multirow{2}{*}{ SEV } & \multirow{2}{*}{ SE } & 23. Promoting AA \\
\hline & & 24. Household income \\
\hline
\end{tabular}

Table 4. Experts for the interjudge technique.

\begin{tabular}{|c|c|c|c|c|c|}
\hline Judge & Area & Current Position & Years & 1st Round & 2nd Round \\
\hline 1 & Architecture & $\begin{array}{l}\text { President of the Professional } \\
\text { Association of Architects Castellón } \\
\text { province }\end{array}$ & 21 & 20 April 2021 & 30 June 2021 \\
\hline 2 & Architecture & $\begin{array}{l}\text { Professor of Building Engineering at } \\
\text { the Universitat Jaume I in Castellón }\end{array}$ & 29 & 14 April 2021 & 30 June 2021 \\
\hline 3 & Urbanism & $\begin{array}{l}\text { Technician of Urbanism Department } \\
\text { in the Castellón Municipality }\end{array}$ & 19 & 14 April 2021 & 1 July 2021 \\
\hline 4 & Architecture & $\begin{array}{l}\text { Professor at the School of } \\
\text { Architecture in Zaragoza }\end{array}$ & 10 & 22 April 2021 & 2 July 2021 \\
\hline 5 & Social Services & $\begin{array}{l}\text { Head of the Social Welfare } \\
\text { Department in the Castellón } \\
\text { Municipality }\end{array}$ & 35 & 22 April 2021 & 2 July 2021 \\
\hline 6 & Economy & $\begin{array}{l}\text { Head of the Interuniversity Institute } \\
\text { of Local Development in the } \\
\text { Valencian Region }\end{array}$ & 33 & 20 April 2021 & 30 June 2021 \\
\hline 7 & Social Services & $\begin{array}{l}\text { Coordinator in the Elderly People } \\
\text { Unit in the Castellón Municipality }\end{array}$ & 29 & 22 April 2021 & 30 June 2021 \\
\hline
\end{tabular}


After completing the survey, the agreement degree was calculated by the percentage according to Cohen's kappa coefficient using the scale $0 \%, 0-20 \%, 21-40 \%, 41-60 \%, 61-80 \%$, $81-99 \%$, and $100 \%$, meaning a poor, slight, fair, moderate, substantial, almost perfect, and perfect agreement, respectively. The average value, $\widetilde{x}$, of each indicator was calculated to obtain an overview for every single indicator. We considered the upper scale part, with values 4 and 5, I and VI, as a criterion to include the indicator whenever at least $61 \%$ of the agreement was reached (substantial, almost perfect or perfect), and rejected the indicator otherwise. A excel sheet was used for calculation of the level of agreement and the statistical basic descriptors (average, minimum, maximum values).

Table 5 summarizes all the results and shows the number of responses per mark in the middle columns and the level of agreement as a percentage in the columns on the right. The last column shows the percentage when considering categories I and VI together. They were almost all higher than $61 \%$, except for the indicator "immigrants" with $57 \%$ agreement. This meant rejecting only one of the 24 indicators, which is presented in the shaded cell in Table 4 . The maximum value was reached in 10 of the 24 indicators, such as "green areas" and "pavements", with perfect agreement (100\%).

Table 5. Evolution of the proposed list through a desk review and interjudge agreement validation.

\begin{tabular}{|c|c|c|c|c|c|c|c|c|c|c|c|c|}
\hline \multirow{2}{*}{ Indicator } & \multicolumn{6}{|c|}{ Evaluation (nr Answers) } & \multicolumn{6}{|c|}{ Level of Agreement (\%) } \\
\hline & 1 & 2 & 3 & 4 & 5 & $\mathbf{x}$ & NI & SI & NIN & $\mathbf{I}$ & VI & $\mathbf{I}+\mathbf{V I}$ \\
\hline UBV.UE.1. Green areas & 0 & 0 & 0 & 3 & 4 & 4.6 & 0 & 0 & 0 & 43 & 57 & 100 \\
\hline UBV.UE.2. Daytime acoustic comfort & 0 & 0 & 1 & 4 & 2 & 4.1 & 0 & 0 & 14 & 57 & 29 & 86 \\
\hline $\begin{array}{l}\text { UBV.UE.3. Nighttime acoustic } \\
\text { comfort }\end{array}$ & 0 & 0 & 1 & 1 & 5 & 4.6 & 0 & 0 & 14 & 14 & 71 & 86 \\
\hline UBV.UE.4. Accessible Paving & 0 & 0 & 0 & 3 & 4 & 4.6 & 0 & 0 & 0 & 43 & 57 & 100 \\
\hline UBV.UE.5. Ramps & 0 & 0 & 0 & 2 & 5 & 4.7 & 0 & 0 & 0 & 29 & 71 & 100 \\
\hline UBV.UE.6. Pavements & 0 & 0 & 0 & 2 & 5 & 4.7 & 0 & 0 & 0 & 29 & 71 & 100 \\
\hline UBV.UE.7. Pedestrian route & 0 & 0 & 0 & 3 & 4 & 4.6 & 0 & 0 & 14 & 57 & 29 & 86 \\
\hline UBV.UE.8. Cleanliness & 0 & 1 & 1 & 1 & 4 & 4.1 & 0 & 14 & 14 & 14 & 57 & 71 \\
\hline UBV.UE.9. Adapted urban furniture & 0 & 0 & 1 & 3 & 3 & 4.3 & 0 & 0 & 14 & 43 & 43 & 86 \\
\hline UBV.I.1. Accessible public transport & 0 & 0 & 1 & 2 & 4 & 4.4 & 0 & 0 & 14 & 29 & 57 & 86 \\
\hline UBV.I.2. Lighting & 0 & 1 & 1 & 2 & 2 & 3.8 & 0 & 17 & 17 & 33 & 33 & 67 \\
\hline UBV.I.3. Adapted traffic lights & 1 & 0 & 2 & 1 & 4 & 4.4 & 14 & 0 & 29 & 14 & 57 & 71 \\
\hline UBV.F.1. Health facilities & 0 & 0 & 1 & 3 & 3 & 4.3 & 0 & 0 & 14 & 43 & 43 & 86 \\
\hline UBV.F.2. Elderly care facilities & 0 & 0 & 1 & 3 & 3 & 4.3 & 0 & 0 & 14 & 43 & 43 & 86 \\
\hline UBV.F.3. Commercial facilities & 0 & 0 & 0 & 3 & 4 & 4.6 & 0 & 0 & 0 & 43 & 57 & 100 \\
\hline UBV.B.1. Buildings' age & 0 & 0 & 2 & 3 & 2 & 4.0 & 0 & 0 & 29 & 43 & 29 & 71 \\
\hline $\begin{array}{l}\text { UBV.B.2. Accessibility in residential } \\
\text { build. }\end{array}$ & 0 & 0 & 1 & 2 & 4 & 4.4 & 0 & 0 & 14 & 29 & 57 & 86 \\
\hline $\begin{array}{l}\text { UBV.B.3. Accessibility in non } \\
\text { residential bu. }\end{array}$ & 0 & 0 & 2 & 1 & 4 & 4.3 & 0 & 0 & 29 & 14 & 57 & 71 \\
\hline SDV.D.1. Population over 64 years & 0 & 1 & 0 & 2 & 4 & 4.3 & 0 & 14 & 0 & 29 & 57 & 86 \\
\hline SDV.D.2. Population over 79 years & 1 & 0 & 1 & 2 & 3 & 3.9 & 14 & 0 & 14 & 29 & 43 & 71 \\
\hline Immigrants & 0 & 2 & 1 & 2 & 2 & 3.6 & 0 & 29 & 14 & 29 & 29 & 57 \\
\hline SDV.D.3. Aging ratio & 0 & 0 & 0 & 3 & 4 & 4.6 & 0 & 0 & 0 & 43 & 57 & 100 \\
\hline $\begin{array}{l}\text { SDV.SO.1. Social services attention to } \\
\text { dep. }\end{array}$ & 0 & 0 & 0 & 4 & 3 & 4.4 & 0 & 0 & 0 & 57 & 43 & 100 \\
\hline SDV.SO.2. Social subsidies & 0 & 0 & 2 & 2 & 3 & 4.1 & 0 & 0 & 29 & 29 & 43 & 71 \\
\hline
\end{tabular}


Table 5. Cont.

\begin{tabular}{|c|c|c|c|c|c|c|c|c|c|c|c|c|}
\hline \multirow{2}{*}{ Indicator } & \multicolumn{6}{|c|}{ Evaluation (nr Answers) } & \multicolumn{6}{|c|}{ Level of Agreement (\%) } \\
\hline & 1 & 2 & 3 & 4 & 5 & $\mathbf{x}$ & NI & SI & NIN & $\mathbf{I}$ & VI & $\mathbf{I}+\mathbf{V I}$ \\
\hline $\begin{array}{l}\text { SDV.SO.3. Participation in civic } \\
\text { community }\end{array}$ & 0 & 0 & 0 & 5 & 2 & 4.3 & 0 & 0 & 0 & 71 & 29 & 100 \\
\hline $\begin{array}{l}\text { SDV.SO.4. Participation in } \\
\text { Governance }\end{array}$ & 0 & 0 & 2 & 3 & 2 & 4.0 & 0 & 0 & 29 & 43 & 29 & 71 \\
\hline SEV.SE.1. Promoting AA & 0 & 0 & 2 & 1 & 4 & 4.3 & 0 & 0 & 29 & 14 & 57 & 71 \\
\hline SEV.SE.2. Household income & 0 & 0 & 1 & 2 & 3 & 3.7 & 0 & 0 & 14 & 29 & 43 & 71 \\
\hline
\end{tabular}

With the open questions in the survey, where the experts were asked to make suggestions, some indicators were proposed to complete the list: degree of cleanliness and urban furniture adapted to the old-aged people in the urban category. Thus, two new indicators were included: UBV.UE.8 and UBV.UE.9. They were added to Table 4 and are depicted in bold.

About the socio-demographic category, one suggestion was to include the number of people older than 74: SDV.D.2. One of the experts suggested splitting the indicator "Participation in Community" into two subindicators: one for civic voluntary participation and the other for participation in government organizations and decision making. Oldaged people's voluntary participation can be measured with the associations registered in the city. However, the second indicator was linked with governance. In fact from 2018, Castellón has had the Council of Old-Aged People, in which the elderly are periodically informed and can assess those issues concerning them (http:/ /www.castello.es/web30/ pages / generico_web10.php? cod $1=25 \& \operatorname{cod} 2=1426$, last accessed on 31 May 2021). It was added to the initial list as SDV.SO.4 in bold. This indicator, together with SEV.SE.1, affects the whole city equally, and it is not possible to disaggregate it by census section. However, it was included because its existence sheds light on some actions performed by Local Administrations to promote elder citizens' well-being.

With the socio-economic category, the judges suggested including unemployment for people older than 60 years. However, this disaggregated information was not found. Unemployment data exist for the whole population in the area (source: Municipality) or are divided into ages (under 25, 25-45, and older than 45 years), but no data are disaggregated into census sections (source: INE).

\subsection{Application to the Case Study}

In order to apply the model, the indicators were measured in areas according to different criteria and on a three normalized values scale, where 0 means no vulnerability, 0.5 means medium vulnerability, and 1 high vulnerability. There is also a threshold value used for evaluation, which depends on the indicator.

Table 6 provides detailed information about the measurements of indicators, along with a brief definition, the source from where data were obtained, and the measurement criteria according to a fixed threshold value. The last column depicts the evaluation in the analyzed area.

As the number of indicators (n) may vary from one category to another and to assign the same weight to each category, the vulnerability index for each dimension and area (Ivulj) was calculated using Equation (1):

$$
I_{j}=\text { Sum of } I_{i} / n
$$

where $I_{j}$ indicates the vulnerability index for dimension or area $j, I_{i}$ is the estimated value for indicator $i$, and $n=$ number of indicators in dimension or area $j$. 
A global index can also be obtained by calculating the mean value of the indices of all the dimensions from detecting vulnerability from an integrated view. The equation for the global index is the sum of all the categories as defined by Equation (2):

$$
\text { IGvul }=\text { Sum Ij/3 }
$$

where IGvul is the global vulnerability index and Ij is the vulnerability index for dimension $\mathrm{j}$.

Figure 6 shows the vulnerability index values obtained for dimensions and areas, as well as the global index.

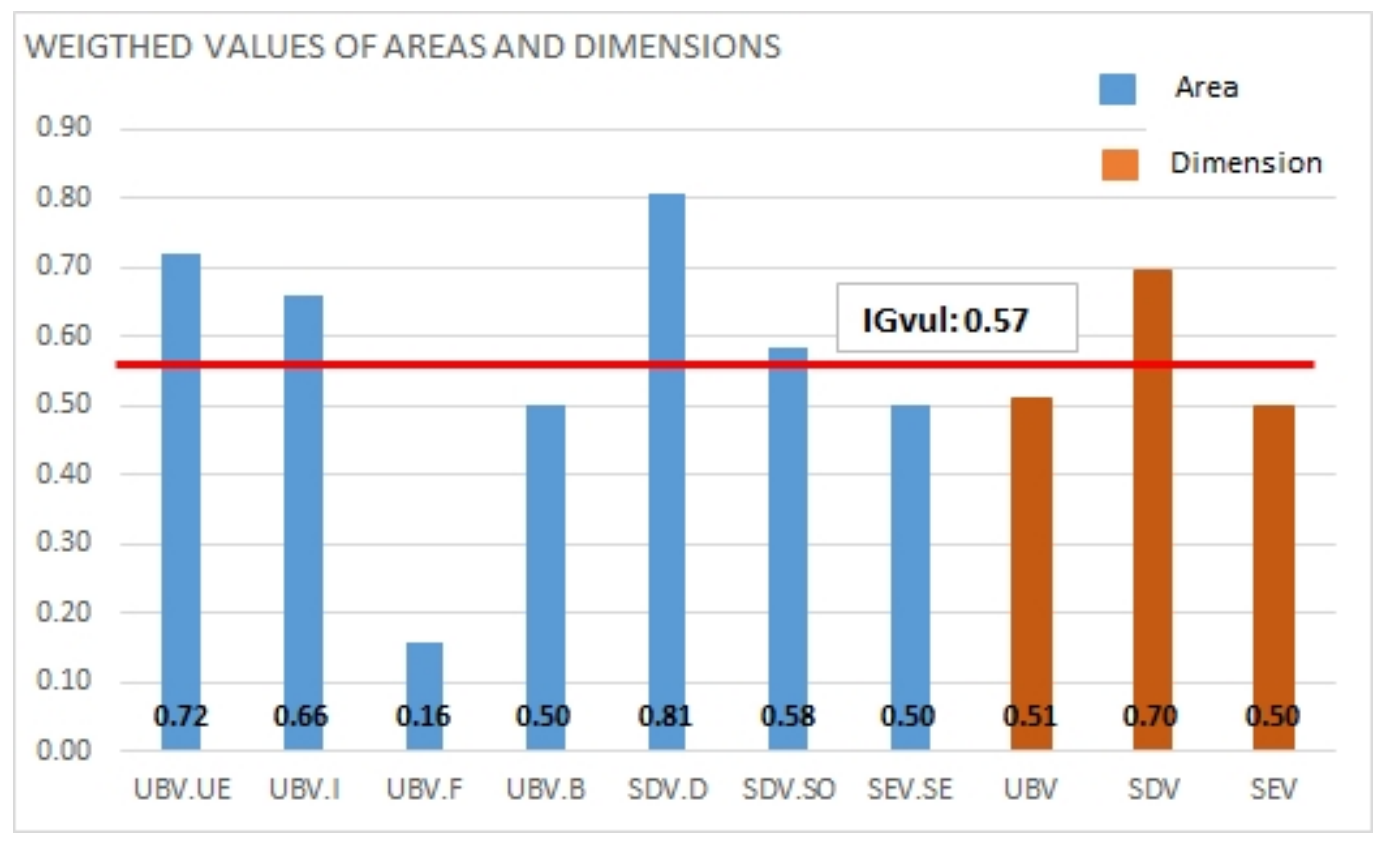

Figure 6. Vulnerability indices per category and dimension and the global index.

Many urban indicators were checked in situ. When calculating indices per area, they all exceeded 0.5 except for the Facilities area.

Urban vulnerability was highest in the Urban Environment area (UBV.UE), reaching 0.72 , followed by the Infrastructure area, 0.66 , but it decreased to 0.16 in the Facilities area, resulting in a global dimension vulnerability UBV of 0.51 . Socio-demographic vulnerability, for demographic area (SDV.SD), was 0.81, which combined with the value 0.58 of the Social area (SDV.SO) resulted in a value for the dimension SDV of 0.70. Socioeconomic dimension had the lowest value of 0.5 .

The global index integrated the three dimensions, resulting in a value of 0.57 .

\section{Discussion and Conclusions}

Population aging is becoming increasingly more important in policies. When it comes to urban planning, the needs and problems that older people encounter should be carefully considered. The biggest challenges for the WHO's AFC concept are found in obsolete and vulnerable areas, which are normally inhabited by elderly people who tend to have lower incomes. The inclusive public space promotes informal relationships and becomes a neighborhood meeting place, where social networks are strengthened and social capital increases. These relationships have a positive effect on the health and quality of life of the elderly. 
Table 6. Details of the evaluation in the area.

\begin{tabular}{|c|c|c|c|c|c|c|}
\hline Indicator & Definition (Source) & Threshold Values. Criteria & Evaluation Scale & Evaluation in the Area & Weight & Vulnerability \\
\hline UBV.UE.1. Green areas & $\begin{array}{l}\text { Green area per inhabitant } \\
\left(\mathrm{m}^{2} / \text { inhabitant. }\right)(1)\end{array}$ & $\begin{array}{l}\text { Threshold value } 10 \mathrm{~m}^{2} / \text { inhabitant. } \\
\text { Minimum value according to World } \\
\text { Health Organization (WHO) criteria and } \\
\text { the Valencian Region Urban Planning and } \\
\text { Landscape Law }\end{array}$ & $\begin{array}{l}<10 \mathrm{~m}^{2} \text { /inh.: } 1 \\
10-15 \mathrm{~m}^{2} / \text { inh.: } 0.5 \\
>15 \mathrm{~m}^{2} / \text { inh.: } 0\end{array}$ & 1 & 1.00 & 1.00 \\
\hline $\begin{array}{l}\text { UBV.UE.2. Daytime } \\
\text { acoustic comfort }\end{array}$ & $\begin{array}{l}\text { Percentage of streets with noise } \\
\text { level } \geq 55 \mathrm{dBA}, 8-22 \mathrm{~h}(1)\end{array}$ & $\begin{array}{l}\text { Level of noise over } 55 \mathrm{dBA} \text { in the daytime } \\
\text { WHO criteria }\end{array}$ & $\begin{array}{l}>55 \text { dBA: } 1 \\
50-55 \text { dBA: } 0.5 \\
<50 \text { dBA: } 0\end{array}$ & 1 & 0.86 & 0.86 \\
\hline $\begin{array}{l}\text { UBV.UE.3. Nighttime } \\
\text { acoustic comfort }\end{array}$ & $\begin{array}{l}\text { Percentage of streets with noise } \\
\text { level }>45 \mathrm{dBA}, 22-8 \mathrm{~h}(1)\end{array}$ & $\begin{array}{l}\text { Level of noise over } 45 \mathrm{dBA} \text {, during night } \\
\text { WHO criteria }\end{array}$ & $\begin{array}{l}>45 \text { dBA: } 1 \\
40-45 \text { dBA: } 0.5 \\
<40 \text { dBA: } 0\end{array}$ & 1 & 0.86 & 0.86 \\
\hline $\begin{array}{l}\text { UBV.UE.4. Accessible } \\
\text { Paving }\end{array}$ & $\begin{array}{l}\text { Percentage of pavements over } \\
1.5 \text { m width }(1-2)\end{array}$ & $\begin{array}{l}\text { (Meters of pavement width }>1.5 \mathrm{~m} / \text { Total } \\
\text { meters of pavements in the area) } \times 100\end{array}$ & $\begin{array}{l}<50 \%: 1 \\
50-75 \%: 0.5 \\
>75 \%: 0\end{array}$ & 0.5 & 1.00 & 0.50 \\
\hline UBV.UE.5. Ramps & $\begin{array}{l}\text { Percentage of slopes under } 8 \% \\
\text { on pavements }(1-2)\end{array}$ & $\begin{array}{l}\text { (Meters of ramps on pavements with } \\
\text { slopes }<8 \% / \text { Total meters of pavement in } \\
\text { the area) } \times 100\end{array}$ & $\begin{array}{l}<50 \%: 1 \\
50-75 \%: 0.5 \\
>75 \%: 0\end{array}$ & 0.5 & 1.00 & 0.50 \\
\hline UBV.UE.6. Pavements & $\begin{array}{l}\text { Percentage of maintained } \\
\text { pavements }(2)\end{array}$ & $\begin{array}{l}\text { (Meters of well-maintained pavement } \\
\mathrm{m} / \text { Total meters of pavement in the area) } \\
\times 100\end{array}$ & $\begin{array}{l}<50 \%: 1 \\
50-75 \%: 0.5 \\
>75 \%: 0\end{array}$ & 0.5 & 1.00 & 0.50 \\
\hline $\begin{array}{l}\text { UBV.UE.7. Pedestrian } \\
\text { itinerary }\end{array}$ & $\begin{array}{l}\text { Percentage of available } \\
\text { pedestrian routes }(1-2)\end{array}$ & $\begin{array}{l}\text { (Meters of available pedestrian } \\
\text { routes/Total meters of routes in the area) } \\
\times 100\end{array}$ & $\begin{array}{l}<25 \%: 0 \\
25-50 \%: 0.5 \\
>50 \%: 1\end{array}$ & 0.5 & 1.00 & 0.50 \\
\hline UBV.UE.8. Cleanliness & $\begin{array}{l}\text { Percentage of cleanliness } \\
\text { observed in the area (2) }\end{array}$ & $\begin{array}{l}\text { (Meters of streets presenting proper } \\
\text { cleanliness/Total meters of streets in the } \\
\text { area) } \times 100\end{array}$ & $\begin{array}{l}\text { No cleanliness: } 1 \\
\text { Medium: } 0.5 \\
\text { Cleanliness: } 0\end{array}$ & 0.5 & 0.71 & 0.36 \\
\hline $\begin{array}{l}\text { UBV.UE.9. Adapted } \\
\text { urban furniture }\end{array}$ & $\begin{array}{l}\text { Existence of adapted urban } \\
\text { furniture (2) }\end{array}$ & Presence of adapted urban furniture & $\begin{array}{l}\text { Scarce: } 1 \\
\text { Medium: } 0.5 \\
\text { Important: } 0\end{array}$ & 1 & 0.86 & 0.86 \\
\hline
\end{tabular}


Table 6. Cont

\begin{tabular}{|c|c|c|c|c|c|c|}
\hline Indicator & Definition (Source) & Threshold Values. Criteria & Evaluation Scale & Evaluation in the Area & Weight & Vulnerability \\
\hline UBV.UE & & & & & & 0.72 \\
\hline $\begin{array}{l}\text { UBV.I.1. Accessible } \\
\text { public transportation }\end{array}$ & $\begin{array}{l}\text { Percentage of accessible public } \\
\text { transport stops (1) }\end{array}$ & $\begin{array}{l}\text { (Number of accessible stops } / \text { total } \\
\text { number of accessible stops) } \times 100\end{array}$ & $\begin{array}{l}<50 \%: 1 \\
50-75 \%: 0.5 \\
>75 \%: 0\end{array}$ & 0.5 & 0.86 & 0.43 \\
\hline UBV.I.2. Lighting & $\begin{array}{l}\text { Percentage of illuminated street } \\
\text { (1) }\end{array}$ & $\begin{array}{l}\text { Minimum values: }<35 \text { lux (road traffic) y } \\
<20 \text { lux (pedestrian streets, inner } \\
\text { courtyards) }\end{array}$ & $\begin{array}{l}<50 \%: 1 \\
50-75 \%: 0.5 \\
>75 \%: 0\end{array}$ & 0.5 & 0.67 & 0.33 \\
\hline $\begin{array}{l}\text { UBV.I.3. Adapted } \\
\text { traffic-lights }\end{array}$ & $\begin{array}{l}\text { Percentage of adapted traffic } \\
\text { lights (1-2) }\end{array}$ & $\begin{array}{l}\text { (Adapted traffic lights/total traffic lights } \\
\text { in the area) } \times 100\end{array}$ & $\begin{array}{l}<50 \%: 1 \\
50-75 \%: 0.5 \\
>75 \%: 0\end{array}$ & 1 & 0.71 & 0.71 \\
\hline UBV.I & & & & & & 0.66 \\
\hline UBV.F.1. Health Facilities & $\begin{array}{l}\text { Proximity to health facilities } \\
(<600 \mathrm{~m})(1-2)\end{array}$ & $\begin{array}{l}\text { Distance from the geometric center of the } \\
\text { neighborhood }<600 \mathrm{~m}\end{array}$ & $\begin{array}{l}<600 \mathrm{~m}: 0 \\
{[600-1000] \mathrm{m}: 0.5} \\
>1000 \mathrm{m:} 1\end{array}$ & 0 & 0.86 & 0.00 \\
\hline $\begin{array}{l}\text { UBV.F.2. Elderly care } \\
\text { Facilities }\end{array}$ & $\begin{array}{l}\text { Proximity to elderly care } \\
\text { facilities }(<300 \mathrm{~m})(1-2)\end{array}$ & $\begin{array}{l}\text { Distance from the neighborhood's } \\
\text { geometric center }<300 \mathrm{~m}\end{array}$ & $\begin{array}{l}<300 \mathrm{~m}: 0 \\
{[300-600] \mathrm{m}: 0.5} \\
>600 \mathrm{~m}: 1\end{array}$ & 0.5 & 0.86 & 0.43 \\
\hline $\begin{array}{l}\text { UBV.F.3. Commercial } \\
\text { Facilities }\end{array}$ & $\begin{array}{l}\text { Proximity to commercial } \\
\text { facilities }(<300 \mathrm{~m})(1-2)\end{array}$ & $\begin{array}{l}\text { Distance from the neighborhood's } \\
\text { geometric center }<300 \mathrm{~m}\end{array}$ & $\begin{array}{l}<300 \mathrm{~m}: 0 \\
{[300-600] \mathrm{m}: 0.5} \\
>600 \mathrm{~m}: 1\end{array}$ & 0 & 1.00 & 0.00 \\
\hline UBV.F & & & & & & 0.16 \\
\hline UBV.B.1. Age buildings & $\begin{array}{l}\text { Percentage of buildings over } 50 \\
\text { years old ( } 3 \text { ) }\end{array}$ & $\begin{array}{l}\text { (Number of buildings }>50 \text { years } / \text { total } \\
\text { number of buildings in the area) } \times 100 \text {. }\end{array}$ & $\begin{array}{l}>75 \%: 1 \\
50-75 \%: 0.5 \\
<50 \%: 0\end{array}$ & 1 & 0.71 & 0.71 \\
\hline $\begin{array}{l}\text { UBV.B.2. Accessibility in } \\
\text { residential buildings }\end{array}$ & $\begin{array}{l}\text { Percentage of inaccessible } \\
\text { residential b. ( } 3-5 \text { floors no } \\
\text { elevator) (3) }\end{array}$ & $\begin{array}{l}\text { (Number of inaccessible buildings/total } \\
\text { number of buildings in the area) } \times 100\end{array}$ & $\begin{array}{l}>25 \%: 1 \\
\text { 10-25\%: } 0.5 \\
<10 \%: 0\end{array}$ & 0.5 & 0.86 & 0.43 \\
\hline $\begin{array}{l}\text { UBV.B.3. Accessibility in } \\
\text { non-residential build. }\end{array}$ & $\begin{array}{l}\text { Percentage of inaccessible non } \\
\text { residential buildings }(2,3)\end{array}$ & $\begin{array}{l}\text { (Number of inaccessible buildings/total } \\
\text { number of buildings in the area) } \times 100\end{array}$ & $\begin{array}{l}>25 \%: 1 \\
\text { 10-25\%: } 0.5 \\
<10 \%: 0\end{array}$ & 0 & 0.71 & 0.00 \\
\hline
\end{tabular}


Table 6. Cont.

\begin{tabular}{|c|c|c|c|c|c|c|}
\hline Indicator & Definition (Source) & Threshold Values. Criteria & Evaluation Scale & Evaluation in the Area & Weight & Vulnerability \\
\hline UBV.B & & & & & & 0.50 \\
\hline UBV & & & & & & 0.51 \\
\hline $\begin{array}{l}\text { SDV.D.2. Population } \\
\text { over } 79 \text { years }\end{array}$ & $\begin{array}{l}\text { Percentage of population over } \\
79 \text { years ( } 4)\end{array}$ & $\begin{array}{l}\text { (Number of persons aged }>79 \text { in the } \\
\text { area/total population in the area) } \times 100 \text {. } \\
\pm 10 \% \text { Mean value in the city } \widetilde{x}: 5.4 \%\end{array}$ & $\begin{array}{l}>1.1 \widetilde{x}: 1 \\
{[0.9 \widetilde{x}, 1.1 \widetilde{x}]: 0.5} \\
<0.9 \widetilde{x}: 0\end{array}$ & 1 & 0.71 & 0.71 \\
\hline SDV.D.3. Aging ratio & $\begin{array}{l}\text { Persons aged } \geq 65 \text { in relation to } \\
\text { persons aged } 15-64\end{array}$ & $\begin{array}{l}\text { (Number persons aged } \geq 65 / \text { number of } \\
\text { persons aged } 15-64) \times 100 \\
\pm 10 \% \text { Mean value in the city } \widetilde{x}: 27.73 \%\end{array}$ & $\begin{array}{l}>1.1 \widetilde{x}: 1 \\
{[0.9 \widetilde{x}, 1.1 \widetilde{x}]: 0.5} \\
<0.9 \widetilde{x}: 0\end{array}$ & 0.5 & 0.57 & 0.29 \\
\hline SDV.D & & & & & & 0.87 \\
\hline $\begin{array}{l}\text { SDV.SO.1. Social } \\
\text { Services attention to dep. }\end{array}$ & $\begin{array}{l}\text { Percentage of interventions for } \\
\text { dependency in the area (5) }\end{array}$ & $\begin{array}{l}\text { (Number of interventions for dependency } \\
\text { in the area/population in the area) } \times 100 \text {. } \\
\pm 10 \% \text { Mean value in the city } \widetilde{x}: 0.98\end{array}$ & $\begin{array}{l}>1.1 \widetilde{x}: 1 \\
{[0.9 \widetilde{x}, 1.1 \widetilde{x}]: 0.5} \\
<0.9 \widetilde{x}: 0\end{array}$ & 1 & 1.00 & 1.00 \\
\hline $\begin{array}{l}\text { SDV.SO.3. Civic } \\
\text { voluntary participation }\end{array}$ & $\begin{array}{l}\text { Percentage of civic associations } \\
\text { in the area for the elderly }\end{array}$ & $\begin{array}{l}\text { (Number of associations for the } \\
\text { elderly/total number of civic associations } \\
\text { in the area) } \times 100 \\
\pm 10 \% \text { Mean value in the city } \widetilde{x}: 4.2 \%\end{array}$ & $\begin{array}{l}>1.1 \widetilde{x}: 1 \\
{[0.9 \widetilde{x}, 1.1 \widetilde{x}]: 0.5} \\
<0.9 \widetilde{x}: 0\end{array}$ & 0 & 0.71 & 0.00 \\
\hline SDV.SO.4. Governance & $\begin{array}{l}\text { Existence of mechanisms for } \\
\text { old-aged people to participate in } \\
\text { the local government }\end{array}$ & $\begin{array}{l}\text { Identification of mechanisms of old-aged } \\
\text { people to participate in the local } \\
\text { government }\end{array}$ & $\begin{array}{l}\text { Non existence: } 1 \\
\text { Existence: } 0\end{array}$ & 0 & 1.00 & 0.00 \\
\hline
\end{tabular}


Table 6. Cont

\begin{tabular}{|c|c|c|c|c|c|c|}
\hline Indicator & Definition (Source) & Threshold Values. Criteria & Evaluation Scale & Evaluation in the Area & Weight & Vulnerability \\
\hline SDV.SO & & & & & & 0.54 \\
\hline SDV & & & & & & 0.70 \\
\hline $\begin{array}{l}\text { SEV.SE.2. Household } \\
\text { Income }\end{array}$ & $\begin{array}{l}\text { Average annual net income per } \\
\text { household (4) }\end{array}$ & $\begin{array}{l}\text { Annual net income per household in } \\
\text { euros } \\
\pm 10 \% \text { Mean value in the city } \widetilde{x}: € 30,929\end{array}$ & $\begin{array}{l}>1.1 \widetilde{x}: 0 \\
{[0.9 \widetilde{x}, 1.1 \widetilde{x}]: 0.5} \\
<0.9 \widetilde{x}: 1\end{array}$ & 1 & 0.71 & 0.71 \\
\hline SEV.SE & & & & & & 0.5 \\
\hline SEV & & & & & & 0.5 \\
\hline
\end{tabular}

Sources: (1) Land Use Plan; (2) In situ measurements; (3) Cadastral Office; (4) National Statistics Office; (5) Municipality. 
In this work, we propose a model for evaluating vulnerability in the public space of an urban area of the city, from the perspective of older people. The model targets vulnerable areas, assuming that they should be prioritized for urban interventions and considering that urban plans can have great potential to improve the quality of life of citizens. In particular, older people could be considered to be a vulnerable population because they face a higher risk of isolation and exclusion as they tend to encounter greater problems in terms of mobility, accessibility, lower income, and so on.

Previous literature on the interaction between the urban space and the elderly (Table 1) and on vulnerability assessment (Table 2) provides a valuable starting point from which to develop a proposal. All the studies on vulnerability consider aspects related to the physical attributes of the urban environment (buildings, infrastructure, urban features ... ), together with population features (demography, social participation, economic status ... ).

Some of the above work is applicable at the local, regional or even national level. In this model, we propose the suburban level because the model has a bottom-up approach, where some on-site measures are needed, together with the availability of social information. Regarding the latter, we propose the inclusion of information from the Social Welfare Services of the local Administration. It is a valuable source that provides a very accurate idea of the vulnerability of older people given that these services manage local resources to promote the well-being of the elderly, making it possible to detect and correct the strengths and weaknesses of policies.

Site- specific features and the availability of information are analyzed in order to propose ad hoc indicators. The level of agreement reached by a panel of experts is used to validate the indicators and to improve the model. Vulnerability is obtained by indicator, area or dimension. A global index can be obtained to compare the vulnerability of areas within a city. For the case study, all the vulnerability indices by dimensions and areas exceed 0.5 in a scale from 0 to 1 , except for the Facilities area, which is 0.16 , probably due to the fact that the neighborhood is located in the city center. By areas, the highest value is 0.81 in Socio-demographic vulnerability, due to the high rate of aging in the area, followed by 0.72 in Urban Environment area, due to the deficiencies in accessibility, lighting, and maintenance, mainly encountered in the inner parts of the neighborhood. The values for the proposed dimensions are $0.50,0.51$, and 0.70 for UBV, SEV, and SDV, respectively. The global index is 0.57 , which confirms the vulnerability of the area. A first look at the results suggests interventions and better maintenance in the urban space, for example, in the renovation of buildings, planting more trees and vegetation, or reducing the noise level in the avenues, among other necessities. The information from the Social Services indicates a high ratio of subsidies demanded in the area, compared to the average ratio for the city. This denotes a high degree of social vulnerability, which is consistent with the data on household income. On the other hand, participation in social life is not an issue in the area and the latest active-aging policies indicate good practices in the city that should be maintained.

The results presented are valid for the local case study outlined in this paper. A different urban area would need to adapt the indicators to its characteristics and starting conditions and to the urban planning requirements set down in the regulations. This makes the model dependent on the availability of reliable and disaggregated information. On the other hand, some of the information is obtained on site, from primary sources, which entails some limitations; on the one hand, for it to be achievable, the scale of application should not exceed the neighborhood scale; and on the other hand, information must be available from the Social Services. The model considers the technical input of experts, as recommended by other studies. The validation of the indicators has been made through the interjudge agreement technique, but other techniques with a panel of experts would be applicable, the main limitation being the selection of appropriate specialists.

The vulnerability values reached by indicators, areas, and dimensions could be useful to allocate funds to mitigate detected weaknesses in the area. The proposed model could be useful to the local public administration in order to facilitate and optimize urban planning 
and management, prioritizing interventions in vulnerable areas. It could be useful to introduce key factors at the regulatory level in order to support urban planners when they are redesigning neighborhoods and to strengthen the sense of community by promoting more age-friendly spaces. In addition, it could be a useful tool for social workers, who could systematically document and evaluate their work intended to develop an age-friendly community and to detect social deficiencies in order to implement appropriate social policies and to intervene at the public policy level.

Author Contributions: Conceptualization, R.A.-F. and M.J.R.; methodology, M.J.R.; software, F.K.; validation, all authors; formal analysis, all authors; investigation, all authors; resources, all authors; data curation, F.K.; writing-original draft preparation, R.A.-F. and M.J.R.; writing-review and editing, professional proofreading service; visualization, R.A.-F. and M.J.R.; supervision, R.A.-F. and M.J.R.; project administration, R.A.-F.; funding acquisition, R.A.-F. All authors have read and agreed to the published version of the manuscript.

Funding: This research was funded by the Regional Valencian Government (Vicepresidencia y Conselleria de Igualdad y Políticas Inclusivas de la Generalitat Valenciana), through Project Fomento de la Investigación en Servicios Sociales de la Comunitat Valenciana [21I158].

Institutional Review Board Statement: Not applicable.

Informed Consent Statement: Not applicable.

Acknowledgments: We thank the panel of experts for their valuable contribution to this work. We also thank the Municipality of Castellón that provided many of the data for research purposes.

Conflicts of Interest: The authors declare no conflict of interest.

\section{References}

1. Jablonska, J.; Trocka-Leszczynska, E. Public Space for Active Senior. Adv. Intell. Syst. Comput. 2020, 1214, 81-88. [CrossRef]

2. Lotfi, S.; Manouchehri, A. Evaluating urban service accessibility in the medium sized cities of Iran. Theor. Empirica 2015, 10, 77-95.

3. Fantova, F. Crisis de los cuidados y servicios sociales. Zerbitzuan 2015, 60, 47-62. [CrossRef]

4. Rocha, H.B. Social work practices and the ecological sustainability of socially vulnerable communities. Sustainability 2018, 10, 1312. [CrossRef]

5. Page, M.J.; Bossuyt, P.M.; Boutron, I.; Hoffman, T.C.; Mulrow, C.D. The PRISMA 2020 statement: An updated guideline for reporting systematic reviews. BMJ 2021,372, 1312. [CrossRef]

6. Colleoni, M. A social science approach to the study of mobility: An introduction. In Understanding Mobilities for Designing Contemporary Cities. Research for Development; Pucci, P., Colleoni, M., Eds.; Springer: Cham, Switzerland, 2016. [CrossRef]

7. Pafka, E.; Dovey, K.; Aschwanden, G.D.P.A. Limits of space syntax for urban design: Axiality, scale and sinuosity. Environ. Plan B Urban Anal. City Sci. 2020, 47, 508-522. [CrossRef]

8. Tang, B.S.; Wong, K.K.H.; Tang, K.S.S.; Wai Wong, S. Walking accessibility to neighbourhood open space in a multi-level urban environment of Hong Kong. Environ. Plan B Urban Anal. City Sci. 2020, 48, 1340-1356. [CrossRef]

9. Alonso López, F. La Accesibilidad en Evolución: La Adaptación Persona-Entorno y su Aplicación al Medio Residencial en España y Europa. Doctoral Thesis, Universidad Autónoma de Barcelona, Barcelona, Spain, July 2016. Available online: https:/ /ddd.uab.cat/record/166087 (accessed on 20 May 2021).

10. Arjona, G. La accesibilidad y el diseño universal entendido por todos. De cómo Stephen Hawking viajó por el espacio. In Democratizando la Accesibilidad; La Ciudad Accesible: Granada, Spain, 2015; Volume 4, Available online: http:/ / riberdis.cedd.net/ handle/11181/4655 (accessed on 2 June 2021).

11. Bianco, L. Universal design: From design philosophy to applied science. J. Access. Des. All. 2020, 10, 70-97. [CrossRef]

12. Bonilla, A.N.; Alcívar, D.E.; García, J.E.; Carrillo, A.J. Movilidad y accesibilidad universal en la arquitectura. Caso Universidad San Gregorio de Portoviejo. Ecuador. Revistarquis 2019, 8, 24-36. [CrossRef]

13. De Asís, R.; Aiello, A.L.; Bariffi, F.; Campoy, I.; Palacios, A. La accesibilidad universal en el marco constitucional español. Revista Derechos y Libertades 2007, 16, 57-82. Available online: http:/ / hdl.handle.net/10016/7130 (accessed on 2 June 2021).

14. Dropkin, D. Accessibility for all. Build. Eng. 2008, 83, 12-13.

15. Olaru, D.; Smith, N.; Ton, T. Activities, Accessibility and Mobility for Individuals and Households. WIT Transactions on the Built Environment. In Proceedings of the 11th International Conference on Urban Transport and the Environment in the 21st Century, Online. 16-18 June 2021; Brebbia, C.A., Wadhwa, L., Eds.; WIT Press: Algarve, Portugal, 2005; Volume 77, pp. 373-383. Available online: https:/ / www.witpress.com/Secure/elibrary/papers/UT05/UT05037FU.pdf (accessed on 21 July 2021).

16. Calonge-Reillo, F. Recursos de movilidad y accesibilidad urbana en los municipios del sur del área metropolitana de Guadalajara, México. Urbano 2018, 21, 48-57. [CrossRef] 
17. Cocco, F.; Alonso-López, F. Ajustes razonables en la rehabilitación de polígonos de viviendas: Aplicación al Barrio Montserrat de Terrassa (Barcelona). Archit. City Environ. 2015, 10, 31-58. [CrossRef]

18. Elkouss, E. La accesibilidad: Hacia la plena integración social del discapacitado en el entorno urbano y natural. Ci[ur]] 2006, 46, 3-87. Available online: http:/ / polired.upm.es/index.php/ciur/article/view/261/256 (accessed on 2 June 2021).

19. Faura-Martínez, U.; Lafuente-Lechuga, M.; García-Luque, O. Riesgo de pobreza o exclusión social: Evolución durante la crisis y perspectiva territorial. Rev. Esp. Invest. Sociol. 2016, 156, 59-76. [CrossRef]

20. Hong, J.; Shing, S.S. A study on infrastructure-centered publicness in urban public space through a look at Dutch architectural policies and practices. J. Asian Archit. Build. Eng. 2016, 15, 33-40. [CrossRef]

21. Kyttä, M.; Broberg, A.; Haybatollahi, M.; Schmidt-Thomé, K. Urban happiness: Context-sensitive study of the social sustainability of urban settings. Environ. Plann. B Plann. Des. 2016, 43, 34-57. [CrossRef]

22. Pitarch-Garrido, M.D.; Salom, J.; Fajardo, F. Detección de barrios vulnerables a partir de la accesibilidad a los servicios públicos de proximidad. El caso de la ciudad de Valencia. An. Geogr. Univ. Complut. 2018, 38, 61-85. [CrossRef]

23. Wu, J.; He, Q.; Chen, Y.; Lin, J.; Wang, S. Dismantling the fence for social justice? Evidence based on the inequity of urban green space accessibility in the central urban area of Beijing. Environ. Plan. B Urban. Anal. City Sci. 2018, 31, 913-930. [CrossRef]

24. Wu, K.C.; Song, L.Y. A case for inclusive design: Analyzing the needs of those who frequent Taiwan's urban parks. Appl. Ergon. 2017, 58, 254-264. [CrossRef]

25. Alipour, S.M.H.; Galal Ahmed, A. Assessing the effect of urban form on social sustainability: A proposed 'Integrated Measuring Tools Method' for urban neighborhoods in Dubai. City Territ. Archit. 2021, 8, 254-264. [CrossRef]

26. Yildiz, S.; Kivrak, S.; Gültekin, A.B.; Arslan, G. Identifying the key factors in construction projects that affect neighbourhood social sustainability. Sustain. Cities Soc. 2020, 60, 102173. [CrossRef]

27. Almahmoud, E.; Doloi, H.K. Built environment design—Social sustainability relation in urban renewal. Facilities 2020, 38, 765-782. [CrossRef]

28. Ahrentzen, S.; Tural, E. The role of building design and interiors in ageing actively at home. Build. Res. Inf. 2015, 43, 582-601. [CrossRef]

29. La Rosa, D.; Takatori, C.; Shimizu, H.; Privitera, R. A planning framework to evaluate demands and preferences by different social groups for accessibility to urban greenspaces. Sustain. Cities Soc. 2010, 36, 346-362. [CrossRef]

30. Fernández, J.L.; Parapar, C.; Ruiz, M. El envejecimiento de la población. Cuadernos de la Fundación General CSIC. LYCHNOS 2018, 2, 6-11. Available online: http://www.fgcsic.es/lychnos/es_es/articulos/envejecimiento_poblacion (accessed on 2 June 2021).

31. Iwarsson, S.; Wilson, G. Environmental barriers, functional limitations, and housing satisfaction among older people in Sweden: A longitudinal perspective on housing accessibility. Technol Disabil. 2006, 18, 57-66. [CrossRef]

32. Pacheco, A. Espacio Público y Envejecimiento Activo en los Barrios Bardegueral y Los Llanos. Territorios en Formación. 2017, 11, 101-119. [CrossRef]

33. Puyuelo, M.; Gual Ortí, J. Diseño prospectivo y elementos de uso en parques urbanos a partir de la experiencia de las personas mayores. Medio Ambiente y Comportamiento Humano 2009, 10, 137-160. Available online: http://repositori.uji.es/xmlui/handle/ 10234/22811 (accessed on 12 October 2020).

34. Yung, E.H.K.; Conejos, S.; Chan, E.H.W. Social needs of the elderly and active aging in public open spaces in urban renewal. Cities 2016, 52, 114-122. [CrossRef]

35. Basbas, S.; Konstantinidou, C.; Gogou, N. Pedestrians' needs in the urban environment: The case of the city of Trikala, Greece. WIT Trans. Built Environ. 2010, 111, 15-52. [CrossRef]

36. Wen, C.; Albert, C.; Von Haaren, C. The elderly in green spaces: Exploring requirements and preferences concerning nature-based recreation. Sustain. Cities Soc. 2018, 38, 582-593. [CrossRef]

37. Shan, W.; Xiu, C.; Ji, R. Creating a Healthy Environment for Elderly People in Urban Public Activity Space. Int. J. Environ. Res. Public Health 2020, 17, 7301. [CrossRef] [PubMed]

38. Chandrasiri, O.; Arifwododo, S. Inequality in Active Public Park: A Case Study of Benjakitti Park in Bangkok, Thailand. Int. J. Procedia Eng. 2017, 198, 193-199. [CrossRef]

39. Lee, C.; Moudon, A.V. Neighbourhood design and physical activity. Build. Res. Inf. 2008, 36, 395-411. [CrossRef]

40. Tao, Z.; Cheng, Y. Modelling the spatial accessibility of the elderly to healthcare services in Beijing, China. Environ. Plan. B Urban Anal. City Sci. 2019, 46, 1132-1147. [CrossRef]

41. Brake, J.F. Identifying appropriate options for delivering urban transportation to older people. WIT Trans. Built Environ. 2008, 101, 57-66. [CrossRef]

42. Espínola, A. Comparativa Sobre Normativa de Accesibilidad en Urbanismo y Edificación en España; La Ciudad Accesible: Granada, Spain, 2018; Available online: http:/ / hdl.handle.net/11181/5367 (accessed on 2 June 2021).

43. Casado, D.; Fantova, F. Los sistemas de bienestar en España: Evolución y naturaleza. Doc. Soc. 2017, 186, 55-80.

44. Urrutia, A. Envejecimiento activo: Un paradigma para comprender y gobernar/Active ageing: A paradigm for understanding and governing. Aula Abierta 2018, 47, 45-54. [CrossRef]

45. López Martínez, A. Análisis de las Relaciones Sociales y la Fragilidad en Mayores de 75 Años Residentes en Castellón de la Plana. Ph.D. Doctoral Thesis, Universitat Jaume I, Castellón, Spain, July 2017. Available online: https:/ /www.tdx.cat/handle/10803/48 1957\#page=1 (accessed on 20 May 2021). 
46. Leiton, Z.E. El envejecimiento saludable y el bienestar: Un desafío y una oportunidad para enfermería / Healthy ageing and well-being: A challenge, but also an opportunity for nursing. Enferm. Univ. 2016, 13, 139-141. [CrossRef]

47. Limón, M.R. Envejecimiento activo: Un cambio de paradigma sobre el envejecimiento y la vejez / Active Aging: A change of paradigm on aging and old age. Aula Abierta 2018, 47, 45-54. [CrossRef]

48. Pérez, J.; Abellán, A.; Aceituno, P.; Ramiro, D. Un Perfil de Las Personas Mayores en España, 2020. Indicadores Estadísticos Básicos. Informes Envejecimiento en Red. Numero, 25. 2020. Available online: http://envejecimiento.csic.es/documentos/ documentos/enred-indicadoresbasicos2020.pdf (accessed on 20 May 2021).

49. Afacan, Y. Elderly-friendly inclusive urban environments: Learning from Ankara. Open House Int. 2013, 38, 52-63. [CrossRef]

50. Elsawahli, H.; Ahmad, F.; Ali, A.S. A qualitative approach to understanding the neighborhood environmental influences on active aging. J. Des. Built Environ. 2017, 17, 16-26. [CrossRef]

51. Musselwhite, C.; Holland, C.A.; Walker, I. The role of transport and mobility in the health of older people. J. Transp. Health 2015, 2, 1-4. [CrossRef]

52. Gharaveis, A. A systematic framework for understanding environmental design influences on physical activity in the elderly population: A review of literature. Facilities 2020, 38, 625-649. [CrossRef]

53. Parra Rizo, M.A. Envejecimiento Activo y Calidad de Vida: Análisis de la Actividad Física y Satisfacción Vital en Personas Mayores de 60 Años. Ph.D. Doctoral Thesis, Universidad Miguel Hernández, Elche, Spain, May 2018. Available online: http:/ / dspace.umh.es/bitstream/11000/4457/1/TD\%20Parra\%20Rizo\%2c\%20Maria\%20Antonia.pdf (accessed on 8 June 2021).

54. Van Hoof, J.; Kazak, J.K.; Perek-Bialas, J.M.; Peek, S.T.M. The Challenges of Urban Ageing: Making Cities Age-Friendly in Europe. Int. J. Environ. Res. Public Health 2018, 15, 2473. [CrossRef]

55. Van Hoof, J.; Kazak, J.K. Urban ageing. Indoor Built Environ. 2018, 27, 583-586. [CrossRef]

56. Zaidi, A.; Howse, K. The Policy Discourse of Active Ageing: Some Reflections. J. Popul. Ageing 2017, 10, 1-10. [CrossRef]

57. Thalassinos, E.; Cristea, M.; Noja, G.G. Measuring acive ageing within the European Union: Implications on economic development. Equilibrium. Q. J. Econ. 2019, 14, 591-609. [CrossRef]

58. Montañés, R. Castellón: Una Ciudad Amigable con las Personas Mayores. Bachelor's Thesis, Jaume I University, Castellón, Spain, May 2017. Available online: http:/ / hdl.handle.net/10234/169038 (accessed on 8 June 2021).

59. Van Hoof, J.; Marston, H.R. Age-friendly cities and communities: State of the art and future perspectives. Int. J. Environ. Res. Public Health 2021, 18, 1644. [CrossRef] [PubMed]

60. De Oliveira, S.M.L.; Pessa, S.L.R.; Schenatto, F.J.; de Lourdes Bernartt, M. Cities and Population Aging: A Literature Review. Adv. Intell. Syst. Comput. 2019, 824, 1644. [CrossRef]

61. Rémillard-Boilard, S.; Bufel, T.; Phillipson, C. Developing Age-Friendly Cities and Communities: Eleven Case Studies from around the World. Int. J. Environ. Res. Public Health 2021, 18, 133. [CrossRef]

62. Sengers, F.; Peine, A. Innovation pathways for age-friendly homes in Europe. Int. J. Environ. Res. Public Health 2021, 18, 1139. [CrossRef] [PubMed]

63. Marquet, O.; Hipp, A.; Miralles-Guasch, C. Neighborhood walkability and active ageing: A difference in differences assessment of active transportation over ten years. J. Transp. Health 2017, 7, 190-201. [CrossRef]

64. Hochstenbach, C. The age dimensions of urban socio-spatial change. Popul. Space Place 2019, 25, e2220. [CrossRef]

65. Zhang, C.J.; Barnett, A.; Johnston, J.M.; Lai, P.C.; Lee, R.S.; Sit, C.H.; Cerin, E. Objectively measured neighbourhood attributes as correlates and moderators of quality of life in older adults with different living arrangements: The ALECS cross-sectional study. Int. J. Environ. Res. Public Health 2019, 16, 876. [CrossRef]

66. Iamtrakul, P.; Chayphong, S.; Klaylee, J. The study on age-friendly environments for an improvement of quality of life for elderly, Asian mega city, Thailand. Lowl. Technol. Int. 2019, 21, 123-133.

67. Fung, J.C. Place Familiarity and Community Ageing-with-Place in Urban Neighbourhoods. In Advances in 21st Century Human Settlements; Leong, C.H., Malone-Lee, L.C., Eds.; Springer: Singapore, 2020. [CrossRef]

68. Del Barrio, E.; Pinzón, S.; Marsillas, S.; Garrido, F. Physical Environment vs. Social Environment: What Factors of Age-Friendliness Predict Subjective Well-Being in Men and Women? Int. J. Environ. Res. Public Health 2021, 18, 798. [CrossRef]

69. Cordero del Castillo, P. European year of active aging and the intergenerational solidarity. Humanismo y Trabajo Social 2012, 11, 101-117. Available online: http:/ / hdl.handle.net/10612/3430 (accessed on 8 June 2021).

70. Flores, R.; Caballer, A.; Alarcón, A. Evaluation of an age-friendly city and its effect on life satisfaction: A two-stage study. Int. J. Environ. Res. Public Health 2019, 16, 5073. [CrossRef]

71. Huenchuan, S. (Ed.) Envejecimiento, Personas Mayores y Agenda 2030 Para el Desarrollo Sostenible: Perspectiva Regional y de Derechos Humanos; Libros de la CEPAL, 154 (LC/PUB.2018/24-P); Comisión Económica para América Latina y el Caribe (CEPAL): Santiago, Chile, 2018; Available online: https:/ / repositorio.cepal.org/bitstream/handle/11362/44369/1/S1800629_es.pdf (accessed on 8 June 2021).

72. Huenchuan, S.; Rivera, E. (Eds.) Experiencias y Prioridades Para Incluir a las Personas Mayores en la Implementación y Seguimiento de la Agenda 2030 para el Desarrollo Sostenible; (LC/MEX/SEM.245/1); Comisión Económica para América Latina y el Caribe (CEPAL): Santiago, Chile, 2019; p. 151. Available online: https://repositorio.cepal.org/handle/11362/44600 (accessed on 8 June 2021).

73. Cucó-Giner, J. Un barrio marginado no es un barrio marginal. A propósito de Nazaret (Valencia). Revista de Dialectología y Tradiciones Populares 2016, 71, 151-171. [CrossRef] 
74. Bayar, R.; Türkoğlu, H. The relationship between living environment and daily life routines of older adults. A/Z ITU J. Fac. Archit. 2021, 18, 29-43. [CrossRef]

75. Carroll, S.; Jesperen, A.P.; Troelsen, J. Going along with older people: Exploring age-friendly neighbourhood design through their lens. J. Hous. Built Environ. 2020, 35, 555-572. [CrossRef]

76. Curl, A.; Mason, P. Neighbourhood perceptions and older adults' wellbeing: Does walking explain the relationship in deprived urban communities? Transp. Res. Part A Policy Pract. 2019, 123, 119-129. [CrossRef]

77. Annear, M.; Keeling, S.; Wilkinson, T.; Cushman, G.; Gidlow, B.; Hopkins, H. Environmental influences on healthy and active ageing: A systematic review. Ageing Soc. 2014, 34, 590-622. [CrossRef]

78. Lai, M.M.; Lein, S.Y.; Lau, S.H.; Lai, M.L. Determinants of age-friendly communities. Gerontechnology 2014, 13, 228. [CrossRef]

79. Mercader-Moyano, P.; Flores-García, M.; Serrano-Jiménez, A. Housing and neighbourhood diagnosis for ageing in place: Multidimensional Assessment System of the Built Environment (MASBE). Sustain. Cities Soc. 2020, 62, 102422. [CrossRef]

80. Ravi, K.E.; Fields, N.L.; Dabelko-Schoeny, H. Outdoor spaces and buildings, transportation, and environmental justice: A qualitative interpretive meta-synthesis of two age-friendly domains. J. Transp. Health 2021, 20, 100977. [CrossRef]

81. Davern, M.; Winterton, R.; Brasher, K.; Woolcock, G. How Can the Lived Environment Support Healthy Ageing? A Spatial Indicators Framework for the Assessment of Age-Friendly Communities. Int. J. Environ. Res. Public Health 2020, $17,7685$. [CrossRef]

82. Lak, A.; Rashidghalam, P.; Amiri, S.N.; Myint, P.K.; Baradaran, H.R. An ecological approach to the development of an active aging measurement in urban areas (AAMU). BMC Public Health 2021, 21, 4. [CrossRef]

83. Astiaso Garcia, D.; Cumo, F.; Pennacchia, E.; Stefanini-Pennucci, V.; Piras, G.; De Notti, V.; Roversi, R. Assessment of a urban sustainability and life quality index for elderly. Int. J. Sustain. Dev. Plan. 2017, 12, 908-921. [CrossRef]

84. Sonmez Turel, H.; Malkoc Yigit, E.; Altug, I. Evaluation of elderly people's requirements in public open spaces: A case study in Bornova District (Izmir, Turkey). Build. Environ. 2007, 42, 2035-2045. [CrossRef]

85. Bosia, D.; Montacchini, E.; Savio, L.; Tedesco, S. Aging-People Accessibility to Urban Garden: A Case Study in Turin. Adv. Intell. Syst. Comput. 2020, 1205, 327-334. [CrossRef]

86. Rehal, P.; Chani, P.S.; Atreya, S.; Sehgal, V. Ageing-Friendly Neighbourhoods: A Study of Mobility and Out-of-Home Activity. Lect. Notes Civ. Eng. 2021, 113, 267-280. [CrossRef]

87. Triviño, M.; Oyarzo, V.; Brito, E.; Vega, P.; Ojeda, M.; Rojas, A.; Ivanissevich, L. Una vejez, una ciudad y un vacío. Una visión in situ de la acogida a la ancianidad que ofrece Rio gallegos, Pcia. de Sta. Cruz, 2015. Informes Científicos Técnicos UNPA 2016, 8, 256-272. [CrossRef]

88. Walker, A.; Maltby, T. Active ageing: A strategic policy solution to demographic ageing in the European Union. Int. J. Soc. Welf. 2012, 21, S117-S130. [CrossRef]

89. Kurek, S.; Rachwal, T. Development of entrepreneurship in ageing populations of the European Union. Procedia Soc. Behav. Sci. Welf. 2011, 19, 397-405. [CrossRef]

90. Garrido, M.; Jaraíz, G. Políticas inclusivas en barrios urbanos vulnerables. Áreas: Revista Internacional de Ciencias Sociales 2017, 36, 141-151. Available online: https://dialnet.unirioja.es/servlet/articulo?codigo=6246390 (accessed on 21 July 2021).

91. Caballer, A.; Castillo, A.; Martínez, M.A.; Flores, R.; Alarcón, A.H.; Agost-Felip, R.; Mulet, M.; Díaz, M.J. Estudio del Envejecimiento Activo en la Ciudad de Castellón Desde el Paradigma de la Organización Mundial de la Salud; Publisher Fundación Dávalos-Fletcher: Castellón de la Plana, Spain, 2017.

92. Giménez-Bertomeu, V.M.; Acebal Fernández, A.; Ferrer-Aracil, J.; Cortés-Florín, E.M.; De Alfonseti Hartmann, N.; Mira-Perceval Pastor, M.T.; Domenech-López, Y. Vulnerabilidad Territorial: Indicadores Para su Medición Desde los Servicios Sociales; Limencop, S.L.: Alicante, Spain, 2020.

93. Sorribes i Monrabal, J.; Perelló Oliver, S. Hacia un sistema de indicadores de vulnerabilidad urbana. Barataria. Revista Castellano Manchega De Ciencias Sociales 2006, 6, 87-103. [CrossRef]

94. Egea, C.; Nieto, J.A.; Domínguez, J.; González, R.A. Vulnerabilidad del tejido social de los barrios desfavorecidos en Andalucía. Análisis y potencialidades. Cuadernos Geográficos 2008, 45, 325-327. [CrossRef]

95. Alguacil, J.; Camacho, J.; Hernández-Ajá, A. La vulnerabilidad urbana en España. Identificación y evolución de los barrios vulnerables. Empiria. Revista de Metodología de Ciencias Sociales 2013, 27, 73-94. [CrossRef]

96. Piñeira-Mantiñán, M.; González-Pérez, J.M.; Lois-González, R.C. Vulnerabilidad urbana y exclusión. La fragmentación social de la ciudad postcrisis. In Nuevos Escenarios Urbanos: Nuevos Conflictos y Nuevas Politicas: XIII Coloquio de Geografía Urbana; Castañer, M., Vicente, J., Feliu, J., Martín-Uceda, J., Eds.; Universitat de Girona: Girona, Spain, 2017; pp. 75-90.

97. Temes, R. Valoración de la vulnerabilidad integral en las áreas residenciales de Madrid. EURE 2014, 40, 119-149. Available online: https:/ / www.eure.cl/index.php/eure/article/view/344/606 (accessed on 8 June 2021). [CrossRef]

98. Temes, R. Visor de Espacios Urbanos Sensibles (VEUS). Una nueva herramienta para intervenir en la ciudad. In Proceedings of the III Internacional Conference ISUF-H. Ciudad Compacta vs. Ciudad Difusa, Guadajalara, Mexico, 18-20 September 2019; Universitat Politècnica de València: Valencia, Spain, 2020; pp. 454-461. [CrossRef]

99. Caravantes, G.M. El Derecho a la Ciudad desde la exclusión residencial: La evolución de los barrios vulnerables de la Comunitat Valenciana. In Proceedings of the XIII International Conference on Virtual City and Territory: "Challenges and Paradigms of the Contemporary City": UPC, Barcelona, Spain, 2-4 October 2019; CPSV: Barcelona, Spain, 2019; p. 8661. [CrossRef] 
100. García-Bernal, D.; Huedo, P.; Babiloni, S.; Braulio, M.; Carrascosa, C.; Civera, V.; Ruà, M.J.; Agost-Felip, M.R. Estudio y Propuesta de Áreas de Rehabilitación, Regeneración y Renovación Urbana, con Motivo de la Tramitación del Plan General Estructural de Castellón de la Plana. Memoria (Tomo I). 2017. Available online: https:/ / s3-eu-west-1.amazonaws.com/urbanismo/TOMO_I.pdf (accessed on 15 April 2021).

101. Ruá, M.J.; Huedo, P.; Civera, V.; Agost-Felip, M.R. A simplified model to assess vulnerable areas for urban regeneration. Sustain. Cities Soc. 2019, 46, 101440. [CrossRef]

102. Cremades, R. Validación de un instrumento para el análisis y evaluación de webs de bibliotecas escolares mediante el acuerdo interjueces. Investig. Bibl. 2017, 31, 127-149. [CrossRef]

103. Dubé, J.É. Evaluación del acuerdo interjueces en investigación clínica. Breve introducción a la confiabilidad interjueces. Rev. Argentina de Clin. Psicol. 2008, 17, 75-80. 